This document is the accepted manuscript version of the following article:

Harris, E., Joss, A., Emmenegger, L., Kipf, M., Wolf, B., Mohn, J., \& Wunderlin, P. (2015). Isotopic evidence for nitrous oxide production pathways in a partial nitritation-anammox reactor. Water Research, 83, 258-270. https://doi.org/10.1016/j.watres.2015.06.040

This manuscript version is made available under the CC-BY-NC-ND 4.0

1icense http://creativecommons.org/1icenses/by-nc-nd/4.0/

\title{
Isotopic evidence for nitrous oxide production pathways in a partial nitritation-anammox reactor
}

\begin{abstract}
Eliza Harris ${ }^{\mathrm{a}, *}$, Adriano Joss ${ }^{\mathrm{b}}$, Lukas Emmenegger ${ }^{\mathrm{a}}$, Marco Kipf ${ }^{\mathrm{b}}$, Benjamin Wolf ${ }^{\mathrm{a}, \mathrm{c}}$, Joachim Mohn ${ }^{\mathrm{a}}$, Pascal Wunderlin ${ }^{\mathrm{b}}$

${ }^{a}$ Laboratory for Air Pollution and Environmental Technology, Empa, Überlandstrasse 129, 8600 Dübendorf, Switzerland

${ }^{b}$ Eawag, Swiss Federal Institute of Aquatic Science and Technology, Überlandstrasse 133, 8600 Dübendorf, Switzerland

${ }^{c}$ Institute of Meteorology and Climate Research (IMK-IFU), Karlsruhe Institute of Technology, Kreuzeckbahnstrasse 19, 82467 Garmisch-Partenkirchen, Germany
\end{abstract}

${ }^{*}$ Corresponding author 
Keywords: nitrous oxide, isotopic composition, laser spectroscopy, nitrifier denitrification, process control

\section{Introduction}

In recent years, interest in wastewater treatment with anaerobic ammonium oxidizers (anammox) has increased, resulting in significant technological developments [64, 24, $23,20,12,16]$, as the process offers the potential for reductions of $>50 \%$ in energy consumption compared to traditional nitrification-denitrification, without decreasing nitrogen removal efficiency [54]. The anammox reaction, which involves conversion of nitrite $\left(\mathrm{NO}_{2}^{-}\right)$and ammonium $\left(\mathrm{NH}_{4}^{+}\right)$to form $\mathrm{N}_{2}$, plays an important role in a diverse range of artificial, marine and terrestrial environments [42, 60, 34, 33, 65]. Wastewater treatment with anammox involves partial nitritation $(\mathrm{PN})$, where $\sim 50 \%$ of $\mathrm{NH}_{4}^{+}$is first oxidised to $\mathrm{NO}_{2}^{-}$by ammonia oxidizing bacteria (AOBs) under oxic conditions, coupled to the anoxic anammox reaction to produce $\mathrm{N}_{2}$. As an organic carbon source is not required, $\mathrm{PN}$-anammox is particularly suited for the treatment of high $\mathrm{NH}_{4}^{+}$, low carbon wastes, such as digester liquor from conventional wastewater treatment.

For process stability in single-reactor $\mathrm{PN}$-anammox systems, it is critical to balance AOB and anammox activity while minimising growth of nitrite-oxidising bacteria (NOBs). This is achieved by controlling the air supply rate to be the rate-limiting factor for AOB activity and therefore for the entire process, thus avoiding nitrite accumulation [23]. Anammox bacteria are inhibited by dissolved oxygen $(D O)$ concentrations higher than $0.2 \mathrm{mg}$ $\mathrm{L}^{-1}(6.25 \mu \mathrm{M})[23]$ and potentially also by high $\mathrm{NO}_{2}^{-}$concentrations (eg. $>600 \mathrm{mg} \mathrm{L} \mathrm{L}^{-1}$ or $10 \mathrm{mM}$ ) [10]. If AOB activity is reduced, $D O$ can increase as less oxygen is consumed in the reactor, inhibiting anammox and interrupting operation. Thus the maximal sustainable treatment rate depends on the sludge activity, which - according to experience from long-term full-scale operations - may not be assumed constant. Online monitoring of $\mathrm{NO}_{2}^{-}$has the potential to serve as control parameter to monitor activity. However, as no 
suitable electrode is available for the online measurement of $\mathrm{NO}_{2}^{-}$, online measurements of $\mathrm{N}_{2} \mathrm{O}$ mixing ratio ${ }^{1}$ have been suggested to act as a proxy for $\mathrm{NO}_{2}^{-}$, thus presenting an ideal method to monitor and control reactor dynamics [70].

Wastewater treatment is an important, growing source of $\mathrm{N}_{2} \mathrm{O}$, through a number of pathways summarised in Table 1 . The wastewater sector currently contributes $\sim 6 \%$ of $\mathrm{N}_{2} \mathrm{O}$ emissions globally, and best estimates predict that emissions from the sector will increase by $>25 \%$ between 1990 and 2020 [4]. $\mathrm{N}_{2} \mathrm{O}$ is a potent greenhouse gas with a global warming potential 298 times higher than $\mathrm{CO}_{2}$ (100-yr) [14] and the most important ozone depleting substance currently released $[9,50]$. Online $\mathrm{N}_{2} \mathrm{O}$ monitoring for process stability results in control and reduction of $\mathrm{N}_{2} \mathrm{O}$ emissions, thus providing an additional benefit in terms of greenhouse gas (GHG) release.

$\mathrm{N}_{2} \mathrm{O}$ production by AOBs can be envisaged as a 'leaky pipeline' [13] because $\mathrm{N}_{2} \mathrm{O}$ is an unwanted by-product during the goal reaction, oxidation of $\mathrm{NH}_{4}^{+}$to $\mathrm{NO}_{2}^{-}$. Two major pathways are implicated in the emission of $\mathrm{N}_{2} \mathrm{O}$ by AOBs: Nitrifier denitrification, and $\mathrm{NH}_{2} \mathrm{OH}$ oxidation (see Table 1). When the overall turnover of $\mathrm{NH}_{4}^{+}$by $\mathrm{AOBs}$ increases, the 'leaking' of $\mathrm{N}_{2} \mathrm{O}$ also increases - thus $\mathrm{N}_{2} \mathrm{O}$ emissions can roughly indicate AOB activity. Biotic and abiotic $\mathrm{N}_{2} \mathrm{O}$ production by hydroxylamine $\left(\mathrm{NH}_{2} \mathrm{OH}\right)$ oxidation can be minimised by keeping the concentration of $\mathrm{NH}_{4}^{+}$relatively low (eg. by intermittent dosing of wastewater); previous studies suggest that even at high $\mathrm{NH}_{4}^{+}$concentrations this pathway contributes less than 20-30\% of total $\mathrm{N}_{2} \mathrm{O}$ emissions in PN-anammox reactors $[43,21]$. In contrast to AOBs, it was generally agreed until recently that anammox bacteria do not produce significant amounts of $\mathrm{N}_{2} \mathrm{O}[26,44]$; results from Lotti et al. (2014) suggest however that up to $0.2 \%$ of nitrogen removed by anammox may in fact be released as $\mathrm{N}_{2} \mathrm{O}$ [36]. This is much lower than the percent of ammonium released as $\mathrm{N}_{2} \mathrm{O}$ by AOBs

\footnotetext{
${ }^{1}$ Mixing ratio is the ratio of the component of interest to the total of all other constituents in a mixture. In this paper, mixing ratio always refers to the molar mixing ratio, ie. ppm $=$ parts per million $=$ moles of X per million moles of the total mixture.
} 
during imbalances in the reactor, thus in a $\mathrm{PN}$-anammox reactor, nitrifier denitrification is expected to dominate $\mathrm{N}_{2} \mathrm{O}$ production. Online $\mathrm{N}_{2} \mathrm{O}$ measurements can therefore act as a proxy for $\mathrm{NO}_{2}^{-}$concentration, which is an indicator for the relative activity of AOBs compared to anammox.

A major challenge for process regulation via $\mathrm{N}_{2} \mathrm{O}$ measurements is the activity of NOBs, which reduce $\mathrm{N}_{2} \mathrm{O}$ emissions from nitrifier denitrification by consuming $\mathrm{NO}_{2}^{-}$. Monitoring the net $\mathrm{NO}_{3}^{-}$production to $\mathrm{NH}_{4}^{+}$consumption ratio (hereafter $r\left(\mathrm{NO}_{3}^{-}\right) / r\left(\mathrm{NH}_{4}^{+}\right)$) which should be approximately $10-11 \%$ due to $\mathrm{NO}_{3}^{-}$production by anammox when NOBs are not active $[55,6]$ - to detect NOB activity is therefore important for process control. In addition, NOB activity should be minimised, eg. with regular washout [23]. Heterotrophic denitrifiers (HET) also release $\mathrm{N}_{2} \mathrm{O}$ during the stepwise reduction of $\mathrm{NO}_{3}^{-}$to $\mathrm{N}_{2}$, however HET activity is minimal in PN-anammox systems due to low organic carbon concentrations [24, 49].

$\mathrm{N}_{2} \mathrm{O}$ can be the most important greenhouse gas released from wastewater treatment and in addition, shows great potential as an online parameter to monitor process conditions in PN-anammox systems. However, a thorough understanding of $\mathrm{N}_{2} \mathrm{O}$ production pathways is lacking, which is necessary both to mitigate emissions and to effectively use online $\mathrm{N}_{2} \mathrm{O}$ measurements for process control. $\mathrm{N}_{2} \mathrm{O}$ isotopic composition is particularly useful to quantify $\mathrm{N}_{2} \mathrm{O}$ production via different pathways (Table 1 ). The most abundant four isotopocules of $\mathrm{N}_{2} \mathrm{O}$ are ${ }^{14} \mathrm{~N}^{14} \mathrm{~N}^{16} \mathrm{O},{ }^{14} \mathrm{~N}^{14} \mathrm{~N}^{18} \mathrm{O},{ }^{14} \mathrm{~N}^{15} \mathrm{~N}^{16} \mathrm{O}(\alpha)$ and ${ }^{15} \mathrm{~N}^{14} \mathrm{~N}^{16} \mathrm{O}(\beta)$. The bulk ${ }^{15} \mathrm{~N}$ isotopic composition refers to the average $\delta^{15} \mathrm{~N}$ at both positions:

$$
\delta^{15} \mathrm{~N}^{\text {bulk }}=\frac{\delta^{15} \mathrm{~N}^{\alpha}+\delta^{15} \mathrm{~N}^{\beta}}{2}
$$

The $\mathrm{N}_{2} \mathrm{O}$ 'site preference' (SP) refers to the difference in ${ }^{15} \mathrm{~N}$ isotopic composition of the 
central $(\alpha)$ position $\mathrm{N}$ compared to the terminal $(\beta)$ position $\mathrm{N}$ :

$$
\mathrm{SP}=\delta^{15} \mathrm{~N}^{\alpha}-\delta^{15} \mathrm{~N}^{\beta}
$$

Site preference of $\mathrm{N}_{2} \mathrm{O}$, unlike $\delta^{15} \mathrm{~N}^{\text {bulk }}$, is independent of the substrate isotopic composition, and it is therefore a robust tool to differentiate between $\mathrm{N}_{2} \mathrm{O}$ production pathways. While isotopic signatures are known for some pathways, as shown in Table 1 [57, 47], characteristic SP values of other pathways, for example the possible production of $\mathrm{N}_{2} \mathrm{O}$ by anammox [36], are still undetermined. In addition, reduction of $\mathrm{N}_{2} \mathrm{O}$ by HET increases the site preference of the remaining $\mathrm{N}_{2} \mathrm{O}$, which can complicate the partitioning of different production pathways. To overcome these difficulties, combination of site preference data with simultaneous measurements of $\delta^{18} \mathrm{O}$ and $\delta^{15} \mathrm{~N}^{\text {bulk }}$ can help to constrain the effect of $\mathrm{N}_{2} \mathrm{O}$ reduction by $\mathrm{HET}[46,63]$. Recent developments in spectroscopy $[66,40,17]$ allow online monitoring of $\mathrm{N}_{2} \mathrm{O}$ isotopic composition including site preference, which can be combined with online measurements of specific reactor operating conditions in a wellmixed experimental system, to investigate $\mathrm{N}_{2} \mathrm{O}$ production and consumption pathways shown in Table 1.

The aim of this study is to investigate the major pathways leading to $\mathrm{N}_{2} \mathrm{O}$ production in a continuously fed $\mathrm{PN}$-anammox reactor, and thereby facilitate the use of online $\mathrm{N}_{2} \mathrm{O}$ measurements to control process stability. A threshold limit for the net production of $\mathrm{N}_{2} \mathrm{O}$ per $\mathrm{NH}_{4}^{+}$consumed in the reactor (hereafter $r\left(\mathrm{~N}_{2} \mathrm{O}\right) / r\left(\mathrm{NH}_{4}^{+}\right)$) is used to automatically control the reactor aeration rate and maintain balance between AOB and anammox activity. We report the first online measurements of $\mathrm{N}_{2} \mathrm{O}$ offgas isotopic composition during wastewater treatment, made possible by developments in laser spectroscopy in recent years $[66,40,17]$. A series of experiments were carried out for targeted investigation of $\mathrm{N}_{2} \mathrm{O}$ production under different conditions. These results will be used to improve our understanding of $\mathrm{N}_{2} \mathrm{O}$ production pathways during $\mathrm{PN}$-anammox treatment, and to 
investigate the possible production of $\mathrm{N}_{2} \mathrm{O}$ by anammox bacteria.

\section{Materials and methods}

\subsection{Pilot-scale partial nitritation-anammox reactor}

The measurements made in this study were carried out using a pilot-scale sequencing batch reactor, which is described in detail in the supplementary information (Section S1.1, Figure S1). The reactor had a maximum fill level of $400 \mathrm{~L}$ and was operated in 'intermittent feeding' mode, which involves semi-continuous addition of supernatant liquor to maintain $\mathrm{NH}_{4}^{+}$concentration at the setpoint over an entire reactor cycle. The one-month measurement period included 32 fill cycles of 9-33 hours, with an average length of 21 hours, designated $a-f f$ as shown in Figure S2. These cycle names will be used throughout the paper to discuss the different experiments. Throughout the paper, production and consumption of nitrogen species (eg. $\mathrm{NH}_{4}^{+}, \mathrm{NO}_{2}^{-}, \mathrm{NO}_{3}^{-}$and $\mathrm{N}_{2} \mathrm{O}$ ) are always reported as net rates.

Measurements were made under both 'baseline' and experimental conditions. Baseline conditions were defined as when $\mathrm{NO}_{2}^{-}$concentration was low $\left(<1 \mathrm{mg}-\mathrm{N} \mathrm{L}^{-1}\right)$ and no compounds were added to perturb the system (see Table 2 and Figure S2 for all cycle designations). During baseline experiments, $\mathrm{N}_{2} \mathrm{O}$ mixing ratios in the offgas were used as a proxy for $\mathrm{NO}_{2}^{-}$concentrations in the reactor in order to infer the relative activity of AOBs vs anammox and regulate reactor aeration accordingly. Minimum (180-200 $\mathrm{L} \mathrm{h}^{-1}$ ) and maximum (400-750 $\mathrm{L} \mathrm{h}^{-1}$ ) ranges for aeration rates were set, between which aeration could automatically vary: When $r\left(\mathrm{~N}_{2} \mathrm{O}\right) / r\left(\mathrm{NH}_{4}^{+}\right)$reached a defined maximum (eg. 0.5 or $1 \%$ ), the aeration flow was reduced to decrease $\mathrm{AOB}$ activity relative to anammox activity (Figure 1). Baseline conditions were considered with both low and high $\mathrm{NH}_{4}^{+}$, whereby $\mathrm{NH}_{4}^{+}$concentration was set to $\sim 10-20 \mathrm{mg}-\mathrm{N} \mathrm{L}^{-1}$ or $100 \mathrm{mg}-\mathrm{N} \mathrm{L}^{-1} \mathrm{~h}^{-1}$ respectively by continuous feeding of digester liquid. 
The reactor was also run under a range of different conditions designed to represent boundary settings for normal operation, in order to test the suitability of online $\mathrm{N}_{2} \mathrm{O}$ measurements for process control by improving our understanding of how the offgas $\mathrm{N}_{2} \mathrm{O}$ mixing ratio responds to various 'extreme' situations. The following short-term experiments were performed:

- increase of the aeration rate,

- external addition of $\mathrm{NO}_{2}^{-}$under both normal and $\mathrm{N}_{2}$ aeration, and

- external addition of $\mathrm{NH}_{2} \mathrm{OH}$

The goal was to favor different $\mathrm{N}_{2} \mathrm{O}$ formation pathways, and to investigate the isotopic end-member signature of the 'unknown' pathway. Isotopic measurements were carried out to gain insight into $\mathrm{N}_{2} \mathrm{O}$ production pathways. The experiments are summarised in Table 2 and an overview of the measurements is given in Figure S2. The results are presented in Section 3.3.

\subsection{Online spectroscopic analysis of trace gas emissions and $\mathrm{N}_{2} \mathrm{O}$ isotopic composition} Isotopic measurements were carried out with a Quantum Cascade Laser Absorption Spectrometer (QCLAS; Aerodyne Research, Inc.) [66, 39, 40] using the set up shown in Figure S1 and described in detail in Section S1.3. In brief, $50 \mathrm{sccm}$ of offgas from the SBR is pulled through an FT-IR (CX 400, Gasmet Technologies Inc.) which measures the mixing ratios of $\mathrm{N}_{2} \mathrm{O}, \mathrm{CO}_{2}, \mathrm{CH}_{4}, \mathrm{CO}$ and $\mathrm{NO}$ with one minute resolution. The FT-IR measurement of $\mathrm{N}_{2} \mathrm{O}$ mixing ratio is used to dynamically dilute the offgas to a mixing ratio of $45 \mathrm{ppm}$, which is then measured in the QCLAS at a pressure of $21 \mathrm{hPa}$ following chemical removal of $\mathrm{CO}_{2}$ and $\mathrm{CO}$ [32].

The isotopic composition of offgas $\mathrm{N}_{2} \mathrm{O}\left(\delta^{15} \mathrm{~N}^{\alpha}, \delta^{15} \mathrm{~N}^{\text {beta }}, \delta^{15} \mathrm{~N}^{\text {bulk }}\right.$ and $\left.\delta^{18} \mathrm{O}\right)$ is measured continuously at one second time resolution over $\approx 30$ minute periods (see Figure S3). Measurements are corrected and calibrated to the international isotopic standard 
scales, V-SMOW (Vienna Standard Mean Ocean Water) for $\delta^{18} \mathrm{O}$ and Air- $\mathrm{N}_{2}$ for $\delta^{15} \mathrm{~N}$ as described in the supplementary information, Section S1.3. Compatibility of $\mathrm{N}_{2} \mathrm{O}$ isotopomer analysis by QCLAS with isotope ratio mass spectrometry (IRMS) laboratories was recently demonstrated in an interlaboratory comparison campaign [41]. Lags in the temporal response of SBR process monitor, FTIR and QCLAS measurements were determined by comparing the $\mathrm{N}_{2} \mathrm{O}$ mixing ratios measured in the three instruments, and all data was corrected to the time scale of the SBR process monitor. Agreement between $\mathrm{N}_{2} \mathrm{O}$ mixing ratios from the three measurements was very good ( $\left.\pm 5-10 \%\right)$, although peaks in $\mathrm{N}_{2} \mathrm{O}$ mixing ratios analysed by QCLAS tended to be slightly dampened due to mixing of process gas in the laser cell.

\section{Results and discussion}

\subsection{Process control using online monitoring of net $\mathrm{N}_{2} \mathrm{O}$ production rate}

\subsubsection{Baseline conditions with low $\mathrm{NH}_{4}^{+}$concentration}

Achieving a balance between $\mathrm{AOB}$ and anammox activity while maintaining low NOB activity is one of the key challenges in $\mathrm{PN}$-anammox reactor systems [23, 70]. Effective process control is therefore a critical factor preceeding the adoption of single-reactor PNanammox systems in full scale wastewater treatment operations [23]. In the combined PN-anammox system used in this study, the $r\left(\mathrm{~N}_{2} \mathrm{O}\right) / r\left(\mathrm{NH}_{4}^{+}\right)$was used as a trigger to set the aeration rate and thus control the relative activities of aerobic AOBs and anaerobic anammox bacteria, as suggested by Wunderlin et al. [70]. Figure 1 illustrates that reactor operation was stable over two full 24 -hour baseline cycles $(j$ and $k$ ). This confirms that online measurement of $\mathrm{N}_{2} \mathrm{O}$ mixing ratio in reactor offgas can be effectively used to control the aeration rate, and thus microbial activities, of a single-stage $\mathrm{PN}$-anammox system under specific baseline conditions. 


\subsubsection{Baseline conditions with high $\mathrm{NH}_{4}^{+}$concentration}

Automatic regulation during baseline cycles with elevated $\mathrm{NH}_{4}^{+}$(setpoint $100 \mathrm{mg}$ $\mathrm{N} \mathrm{L}^{-1} \mathrm{~h}^{-1}$ ) was tested, to investigate $\mathrm{N}_{2} \mathrm{O}$ production with higher $\mathrm{NH}_{4}^{+}$consumption rates. At high $\mathrm{NH}_{4}^{+}$concentrations, $\mathrm{N}_{2} \mathrm{O}$ emissions can be expected to increase $[69$, 48]. This was confirmed with the results of this study. When the $\mathrm{NH}_{4}^{+}$setpoint was $100 \mathrm{mg}-\mathrm{N} \mathrm{L}^{-1}$ (cycle $n$ ), the inital $\mathrm{NH}_{4}^{+}$consumption rate was much higher than under baseline conditions; $30 \mathrm{mg}-\mathrm{N} \mathrm{L}^{-1} \mathrm{~h}^{-1}$ compared to $<10 \mathrm{mg}-\mathrm{N} \mathrm{L}^{-1} \mathrm{~h}^{-1}$ with low $\mathrm{NH}_{4}^{+}$ load (Figure 1). In the initial phase of cycle $n$ (up to 4 hours after onset) both the net $\mathrm{N}_{2} \mathrm{O}$ production rate $\left(0.3 \mathrm{mg}-\mathrm{N} \mathrm{L}^{-1} \mathrm{~h}^{-1}\right.$, average over complete cycle $0.08 \mathrm{mg}-\mathrm{N} \mathrm{L}^{-1}$ $\left.\mathrm{h}^{-1}\right)$ and the $\mathrm{NH}_{4}^{+}$consumption rate peaked, although the $r\left(\mathrm{~N}_{2} \mathrm{O}\right) / r\left(\mathrm{NH}_{4}^{+}\right)$ratio was not especially high at this point. Around 5 hours after the onset of cycle $n, \mathrm{~N}_{2} \mathrm{O}$ emissions and the $r\left(\mathrm{~N}_{2} \mathrm{O}\right) / r\left(\mathrm{NH}_{4}^{+}\right)$drastically increased, thus the aeration rate was automatically reduced and consequently $\mathrm{NH}_{4}^{+}$consumption rate decreased. Throughout the rest of the cycle, $\mathrm{N}_{2} \mathrm{O}$ emissions varied cyclically in response to the automatic regulation of the aeration rate. We did not observe an increase in either $\mathrm{NO}_{2}^{-}$concentration or net $\mathrm{NO}_{3}^{-}$ production rate during high $\mathrm{NH}_{4}^{+}$experiments $\left(\mathrm{NO}_{3}^{-}\right.$production level was $10.4 \pm 2.4 \%$ of $\mathrm{NH}_{4}^{+}$consumption; similar to low $\mathrm{NH}_{4}^{+}$baseline data at $\mathrm{p}<0.05$ ), showing that the anammox population was strong, while the NOB population in the reactor was weak and the NOB washout and aeration control were effective.

Although the online $\mathrm{N}_{2} \mathrm{O}$ measurement was able to control the process to achieve approximately the desired ratio of $\mathrm{N}_{2} \mathrm{O}$ production to $\mathrm{NH}_{4}^{+}$consumption (with minimal $\mathrm{NO}_{3}^{-}$production) even at high $\mathrm{NH}_{4}^{+}$concentration (cycle $n$ ), the system was in a much more dynamic state than with a low $\mathrm{NH}_{4}^{+}$concentration (Figure 1). This resulted in much larger variations in aeration rate and $r\left(\mathrm{~N}_{2} \mathrm{O}\right) / r\left(\mathrm{NH}_{4}^{+}\right)$than under low $\mathrm{NH}_{4}^{+}$conditions (cycles $j$ and $k$ ). Consistent results have been observed in previous studies, which also reported peak $\mathrm{N}_{2} \mathrm{O}$ emissions when $\mathrm{NH}_{4}^{+}$concentrations were high, attributed to enhanced 
nitrifier denitrification $[21,51,35]$. The $\mathrm{NH}_{4}^{+}$consumption peak at the beginning of cycle $n$ is most likely due to enhanced AOB activity, however the current understanding of $\mathrm{NH}_{4}^{+}$and $\mathrm{NO}_{3}^{-}$consumption and $\mathrm{N}_{2} \mathrm{O}$ production pathways does not allow us to interpret features of both the baseline and high $\mathrm{NH}_{4}^{+}$measurements based on $\mathrm{N}_{2} \mathrm{O}$ mixing ratio and process parameters alone. Therefore, in the following section the isotopic composition of $\mathrm{N}_{2} \mathrm{O}$ emitted from the reactor under baseline conditions (both low and high $\mathrm{NH}_{4}^{+}$) will be discussed, to understand which pathway(s) contribute the majority of $\mathrm{N}_{2} \mathrm{O}$ emissions.

\subsection{Isotopic composition of $\mathrm{N}_{2} \mathrm{O}$ produced under baseline conditions (low and high $\mathrm{NH}_{4}^{+}$ concentrations)}

Baseline experiments with low $\mathrm{NH}_{4}^{+}$represent optimal operating conditions, therefore the isotopic measurements made during these experiments reveal the $\mathrm{N}_{2} \mathrm{O}$ production pathway(s) that will be most important in a stable reactor (Section 3.1.1). The mean SP during baseline experiments with low $\mathrm{NH}_{4}^{+}$was $34.3 \pm 2.8 \%$ (Figure 2). This is significantly higher than SP values reported for conventional treatment systems, where measured SP was between 4.5 and $23 \%$ [49,62], and compared to between 4.9 and $14.1 \%$ for a batch-fed heterotrophic $\mathrm{PN}$ reactor with high concentrations of $\mathrm{NH}_{4}$ athd $\mathrm{NO}_{2}^{-}[21] . \quad$ All the measured SP values under baseline conditions in the present study were larger than $28 \%$, which is much higher than previously measured values (Figure 2). In $36 \%$ of measurements, the SP was even larger than $36 \%$, which is the highest currently measured value for any known production pathway [15] (Table 1) - although it is possible that previous studies do not encompass the full range of process conditions and thus of isotopic fractionation factors that are possible for known reaction pathways.

At high $\mathrm{NH}_{4}^{+}$concentrations under baseline conditions (cycle $n$; Section 3.1.2), SP was $28.3 \pm 1.9 \%$; this is significantly lower than with low $\mathrm{NH}_{4}^{+}$concentrations $(\mathrm{p}<0.001)$ but still higher than reported previous studies. This finding is quite surprising, since based on the current understanding, a higher contribution from the $\mathrm{NH}_{2} \mathrm{OH}$ pathway is expected 
at higher $\mathrm{NH}_{4}^{+}$concentrations, resulting in $\mathrm{SP}$ values closer to $33 \%$ [57, 69]. However, the $\mathrm{SP}$ values for $\mathrm{N}_{2} \mathrm{O}$ produced during both low and high ammonium concentrations under baseline conditions were close to previously measured values for $\mathrm{N}_{2} \mathrm{O}$ from $\mathrm{NH}_{2} \mathrm{OH}$ oxidation. A low contribution of $\mathrm{NH}_{2} \mathrm{OH}$ oxidation to $\mathrm{N}_{2} \mathrm{O}$ production is supported by the observed lowest SP values when the $\mathrm{NH}_{4}^{+}$consumption rate $\left(r\left(\mathrm{NH}_{4}^{+}\right)\right)$was highest at the beginning of cycle $n(24.5 \pm 0.5 \%$; $\mathrm{p}<0.001)$.

Over the entire course of the experiments (all experiments, including baseline), higher concentrations of $\mathrm{NO}_{2}^{-}$resulted in enhanced $\mathrm{N}_{2} \mathrm{O}$ emissions with low SP (Figure S4), showing enhanced nitrifier denitrification consistent. SP of 4.9-14.1\%o was measured in a batch-fed reactor with $\mathrm{NH}_{4}^{+}>200 \mathrm{mg}-\mathrm{N} \mathrm{L}^{-1}$ and elevated $D O$ where $\mathrm{N}_{2} \mathrm{O}$ emissions were $5.6 \%$ of $\mathrm{NH}_{4}^{+}$turnover [21]. Our results show that higher $\mathrm{NH}_{4}^{+}$and $\mathrm{DO}$ result in lower SP and more $\mathrm{N}_{2} \mathrm{O}$, thus extrapolating to the conditions in [21] suggests that our measurements are consistent with the results presented by [21]. Higher $\mathrm{NH}_{4}^{+}$concentrations and conversion rates therefore seem to support $\mathrm{N}_{2} \mathrm{O}$ formation via the nitrifier denitrification pathway.

In summary, isotopic data under baseline conditions (with both low and high $\mathrm{NH}_{4}^{+}$ concentrations) showed surprisingly high SP values, which are difficult to explain based on the current understanding of $\mathrm{N}_{2} \mathrm{O}$ formation mechanisms. The following hypotheses may offer an explanation for our findings:

i) significant reduction of $\mathrm{N}_{2} \mathrm{O}$ by HET causing increased $\mathrm{SP}$ in the residual $\mathrm{N}_{2} \mathrm{O}$,

ii) a significant contribution from an unknown $\mathrm{N}_{2} \mathrm{O}$ production pathway with high SP, and/or

iii) previous measurements of $\mathrm{SP}$ from the $\mathrm{NH}_{2} \mathrm{OH}$ oxidation pathway are too low, either due to influence from $\mathrm{N}_{2} \mathrm{O}$ produced via denitrification during experiments, or an incomplete coverage of all process conditions and thus of the total range of fractionation factors. 
The potential role of heterotrophic $\mathrm{N}_{2} \mathrm{O}$ reduction (hypothesis i) during baseline conditions was considered based on the relationship between net $\mathrm{N}_{2} \mathrm{O}$ production rate, SP and $\delta^{18} \mathrm{O}$ under low $\mathrm{NH}_{4}^{+}$baseline conditions (Figure 2; [46, 63]). Figure 2 displays a considerable increase in both $\delta^{18} \mathrm{O}$ and SP with decreasing $\mathrm{N}_{2} \mathrm{O}$ net $\mathrm{N}_{2} \mathrm{O}$ production. For the maximum net $\mathrm{N}_{2} \mathrm{O}$ production rate $\left(0.086 \mathrm{mg}-\mathrm{N} \mathrm{L}^{-1} \mathrm{~h}^{-1}\right), \mathrm{N}_{2} \mathrm{O}$ with a $\mathrm{SP}=30.2 \%$ and $\delta^{18} \mathrm{O}=44.1 \%$ was observed; this was assumed to be the data least affected by heterotrophic $\mathrm{N}_{2} \mathrm{O}$ reduction to $\mathrm{N}_{2}$. Assuming a constant $\mathrm{N}_{2} \mathrm{O}$ source process or mixture of processes (ie. constant isotopic source signature) and fractionation factors for $\mathrm{N}_{2} \mathrm{O}$ reduction $\left(\epsilon_{18}\right.$ and $\epsilon_{\mathrm{SP}}$ of $-12.6 \pm 5.4$ and $-5.6 \pm 1.9 \%$ respectively; see Table $\left.\mathrm{S} 2\right)$, the isotopic composition of $\mathrm{N}_{2} \mathrm{O}$ that would be emitted after partial heterotrophic reduction can be estimated. In Figure 2 the range of $\delta^{18} \mathrm{O}$ versus SP values expected after partial $\mathrm{N}_{2} \mathrm{O}$ reduction is given together with the data obtained from the low $\mathrm{NH}_{4}^{+}$baseline measurements.

It can be seen that the isotopic changes observed in relation to the $\mathrm{N}_{2} \mathrm{O}$ production rates are not consistent with $\mathrm{N}_{2} \mathrm{O}$ reduction being responsible for high $\mathrm{SP}$ at low $\mathrm{N}_{2} \mathrm{O}$ mixing ratio, considering previous measurements of isotopic fractionation. Nearly all the measurement points are outside of the $1 \sigma$ range for $\mathrm{N}_{2} \mathrm{O}$ reduction from previous studies (Figure 2). Correspondingly, the ratio of $\epsilon_{18}: \epsilon_{\mathrm{SP}}$ in this study is smaller than 1 , which has only been observed in one study looking at reduction in soils [31] (see Table S2). A potential explanation for this is oxygen isotope exchange during the formation of $\mathrm{N}_{2} \mathrm{O}$, as observed in a number of studies [7, 30, 29, 67]; although a 'normal' slope of 1.1-1.2 was seen by [67] following extensive $\mathrm{O}$ isotope exchange during $\mathrm{N}_{2} \mathrm{O}$ formation, followed by extensive reduction of $\mathrm{N}_{2} \mathrm{O}$ by denitrifiers. The anomalously low $\epsilon_{18}: \epsilon_{\mathrm{SP}}$ ratio of 0.69 observed by [31] for clayey soils was attributed to $\delta^{18} \mathrm{O}$ fractionation during $\mathrm{N}_{2} \mathrm{O}$ diffusion through water, while SP was not fractionated. However, even this slope is much steeper than the $\epsilon_{18}: \epsilon_{\mathrm{SP}}$ relationship observed in the present study. It is possible that diffusion effects on $\delta^{18} \mathrm{O}$ were particularly strong in the present study, resulting in a very low $\epsilon_{18}: \epsilon_{\mathrm{SP}}$ 
[31], thus other evidence for the extent of HET activity should be examined.

HET they would need to reduce $>70 \%$ of $\mathrm{N}_{2} \mathrm{O}$ to achieve the highest SP values observed in this study ${ }^{2}$. However, HET activity is expected to be low as the $\mathrm{NH}_{4}^{+}$to COD ratio is low ( 1:1, compared to 1:8-1:10 for typical municipal wastewater; see Table S1 for full details of influent water quality) $[24,49,62]$; in addition, the supernatant liquor used in this study has already passed an aerobic (sludge formation) and anaerobic (sludge digestion) stage, thus the COD remaining is quite refractory to microbial degradation. High HET activity, to reduce $>70 \%$ of $\mathrm{N}_{2} \mathrm{O}$, should be evident through reduced $\mathrm{NO}_{3}^{-}$ concentration and decreased ratio of $\mathrm{NO}_{3}^{-}$production to $\mathrm{NH}_{4}^{+}$consumption. There was, however, no correlation between SP and $r\left(\mathrm{NO}_{3}^{-}\right) / r\left(\mathrm{NH}_{4}^{+}\right)$- in fact, the highest site preferences were simultaneous with some of the highest $\mathrm{NO}_{3}^{-}$production rates (data not shown). Although Ishii et al. [21] observed that HET activity was strong enough for HET $\mathrm{N}_{2} \mathrm{O}$ production to be the major $\mathrm{N}_{2} \mathrm{O}$ source in a heterotrophic $\mathrm{PN}$ reactor, $\mathrm{N}_{2} \mathrm{O}$ reduction in their study was only strong enough to bring SP to a maximum of $14 \%$.

In summary, the results during baseline conditions are not consistent with strong heterotrophic $\mathrm{N}_{2} \mathrm{O}$ reduction causing the observed high SP, thus the other potential explanations for the data should be considered. The currently accepted fractionation factors for the $\mathrm{N}_{2} \mathrm{O}$ production pathways shown in Table 1 are not able to explain the measured isotopic composition under baseline conditions. It is possible that the fractionation factor for $\mathrm{N}_{2} \mathrm{O}$ production from $\mathrm{NH}_{2} \mathrm{OH}$ oxidation has been strongly underestimated in previous studies, due to inorganic $\mathrm{N}_{2} \mathrm{O}$ production occurring simultaneously to reduce the isotopic composition of the final measured $\mathrm{N}_{2} \mathrm{O}$ in these studies - or the fractionation factors for $\mathrm{N}_{2} \mathrm{O}$ reduction in Table $\mathrm{S} 2$ could be an incomplete assessment of the 'true' range of $\epsilon_{18} / \epsilon_{\text {SP }}$. Alternatively, an unknown microbial or inorganic $\mathrm{N}_{2} \mathrm{O}$ production pathway with high SP could be occurring. Various targeted experiments will be discussed in the 
following sections to distinguish between these and other possible explanations.

\subsubsection{Principal components analysis}

To identify the most important factors regulating $\mathrm{N}_{2} \mathrm{O}$ production pathways so that the various potential hypotheses could be examined with specific experiments, the parameters affecting $\mathrm{N}_{2} \mathrm{O}$ production and isotopic composition under low $\mathrm{NH}_{4}^{+} \quad$ baseline conditions were examined with principal components analysis (PCA, described in Section S1.4). Simple regression between SP and potential controlling factors such as $\mathrm{pH}$ or $\mathrm{T}$ could not provide useful results due to the complexity of the data set and strong intercorrelations between the many parameters monitored. Nine PCs were identified, with PC1 accounting for $43 \%$ of the variability (Figure S5). PC1 shows a strong relationship between $\mathrm{SP}, \delta^{18} \mathrm{O}$ and $\delta^{15} \mathrm{~N}^{\text {bulk }}$, which correlate inversely with net $\mathrm{N}_{2} \mathrm{O}$ production $\left(\mathrm{N}_{2} \mathrm{O}\right.$ mixing ratio, net $\mathrm{N}_{2} \mathrm{O}$ production rate $\left(r \mathrm{~N}_{2} \mathrm{O}\right)$ and $\left.r\left(\mathrm{~N}_{2} \mathrm{O}\right) / r\left(\mathrm{NH}_{4}^{+}\right)\right)$and $D O$. This suggests that during baseline conditions, $D O$ is the most important factor controlling partitioning of $\mathrm{N}_{2} \mathrm{O}$ production between nitrifier denitrification (high production at high $D O$ with low $\mathrm{SP}$ ) and other production pathway(s) (characterised by low production at low DO with high SP). In contrast, $\mathrm{NO}_{3}^{-}\left(r\left(\mathrm{NO}_{3}^{-}\right)\right.$and $\left.\mathrm{NO}_{3}^{-} / \mathrm{NH}_{4}^{+}\right)$is unimportant in $\mathrm{PC}$, which is consistent with a minor role of HETs and NOBs under baseline conditions. $\mathrm{NH}_{4}^{+}$concentration is also unimportant in determining isotopic composition under baseline conditions, which suggests that $\mathrm{N}_{2} \mathrm{O}$ production via $\mathrm{NH}_{2} \mathrm{OH}$ oxidation is minor in this reactor as observed in previous studies, because this pathway is expected to be sensitive to the availability of $\mathrm{NH}_{4}^{+}[69,21,43,48]$.

Overall, the measurements taken during baseline conditions are most consistent with hypothesis ii) above: A previously-unidentified $\mathrm{N}_{2} \mathrm{O}$ production pathway is occurring in

\footnotetext{
${ }^{2}$ Considering $100 \%$ of the initial released $\mathrm{N}_{2} \mathrm{O}$ was derived from $\mathrm{NH}_{2} \mathrm{OH}$ oxidation with $\mathrm{SP}=33 \%$, $\epsilon_{\mathrm{SP}}=-5.6$ (Table S2), and a maximum measured SP of 39.7\%o, and using the equation $\delta=\delta_{0}+\epsilon_{\mathrm{SP}} \ln f$ $[38,46], f$ is equal to 0.3 thus $70 \%$ of the $\mathrm{N}_{2} \mathrm{O}$ must be reduced. This represents a minimum level of reduction, as it is highly unlikely $100 \%$ of the initial $\mathrm{N}_{2} \mathrm{O}$ was from $\mathrm{NH}_{2} \mathrm{OH}$ oxidation, thus $\delta_{0}$ is likely $<33 \%$.
} 

denitrification pathway and/or $\mathrm{NH}_{2} \mathrm{OH}$ oxidation (end-member SPs of $\approx 0 \%$ and $\approx 36833 \%$ respectively; Table 1) - by reversibly inhibiting anammox and HET activity through 369 elevated dissolved oxygen concentrations. The PCA of the baseline data revealed that ${ }_{370} D O$ was the most important parameter controlling $\mathrm{N}_{2} \mathrm{O}$ production pathways and isotopic ${ }_{371}$ composition (Figure S5), although changes in DO during baseline conditions were small $372(0.5-54.4 \mu \mathrm{g} \mathrm{L}$ $\left.{ }^{-1} ; 0.02-1.7 \mu \mathrm{M}\right)$. The aeration rate was manually increased from 250-750 
$\mathrm{L} \mathrm{h}^{-1}$ during baseline conditions to $1500-3000 \mathrm{~L} \mathrm{~h}^{-1}$, with normal $\mathrm{NH}_{4}^{+}$setpoint (20-30 mg-N L${ }^{-1}$ ) in cycle $s$ and the start of cycle $a a(a a(1))$ and higher $\mathrm{NH}_{4}^{+}$setpoints (50$\left.60 \mathrm{mg}-\mathrm{N} \mathrm{L}^{-1}\right)$ later in cycle $a a(a a(2))$, as shown in Figure 3. High aeration increased $D O$ to $>0.2 \mathrm{mg} \mathrm{L}^{-1}(>6.25 \mu \mathrm{M})$, reversibly inhibiting anammox, which are inhibited by relatively low dissolved oxygen concentrations in suspended biomass systems [6, 23]. It is possible some anammox activity remained in anoxic microsites, however this is assumed to be very low as evidenced by rapid $\mathrm{NO}_{2}^{-}$build-up. High $D O$ can also potentially lower HET activity, particularly nitrous oxide reductase activity [11, 3, 37], although previous studies suggest that nitrous oxide reductase can be active at $D O$ up to $5 \mathrm{mg} \mathrm{L}^{-1}$ (156 $\mu \mathrm{M})[28]$.

In the absence of significant anammox activity, $\mathrm{NO}_{2}^{-}$accumulated up to $50 \mathrm{mg}-\mathrm{N} \mathrm{L}^{-1}$ during the peak $D O$ period in cycle $s\left(\mathrm{NO}_{2}^{-}\right.$was not measured during cycle $\left.a a\right)$. In parallel, the $\mathrm{NH}_{4}^{+}$consumption rate and the net $\mathrm{N}_{2} \mathrm{O}$ and $\mathrm{NO}$ production rates increased, and the SP and $\delta^{18} \mathrm{O}$ strongly decreased (grey shading in Figure 3). SP values close to $0 \%$ indicate that $\mathrm{N}_{2} \mathrm{O}$ production is primarily via nitrifier denitrification or heterotrophic denitrification, consistent with the increase in NO production [11, 2, 48]. However, a strong increase in $\mathrm{N}_{2} \mathrm{O}$ production via heterotrophic denitrification is not consistent with increased $\mathrm{NH}_{4}^{+}$consumption rate, as heterotrophs do not consume $\mathrm{NH}_{4}^{+}$. Therefore, the low SP and the increase in $\mathrm{NH}_{4}^{+}$consumption rate together indicate that nitrifier denitrification by $\mathrm{AOBs}$ is responsible for the large spikes in $\mathrm{N}_{2} \mathrm{O}$ production under high aeration.

The minimum SP value reached at the peak $D O$ in each high aeration period (values shown in Figure 3) correlates with the $\mathrm{NH}_{4}^{+}$setpoint during the increased aeration. This can be explained by $\mathrm{NH}_{2} \mathrm{OH}$ oxidation, which is expected to be enhanced at high $\mathrm{NH}_{4}^{+}$concentration in the presence of abundant $D O[69,43]$. However, the low SP values under these conditions show that $\mathrm{NH}_{2} \mathrm{OH}$ oxidation makes a small contribution to $\mathrm{N}_{2} \mathrm{O}$ production - although its importance does in fact increases with increasing concentration 
of $\mathrm{NH}_{4}^{+}$. Even at $\mathrm{NH}_{4}^{+}=50 \mathrm{mg}-\mathrm{N} \mathrm{L}^{-1}\left(D O>1 \mathrm{mg} \mathrm{L}^{-1}(31 \mu \mathrm{M})\right.$, cycle $\left.a a(2)\right)$, SP is $1.8 \%$ (Figure 3), thus $\mathrm{NH}_{2} \mathrm{OH}$ oxidation contributes $<8 \%$ of $\mathrm{N}_{2} \mathrm{O}$ production [57]. This suggests that this pathway will also be relatively unimportant throughout the experimental period, consistent with baseline results (Section 3.2) and previous laboratory [21, 69] and modelling [43] studies.

$\mathrm{N}_{2} \mathrm{O}$ production rate and offgas mixing ratio were observed to increase as $D O$ was raised in the high aeration experiments, due to a shift in production pathways. The increase was strong even though elevated $\mathrm{NO}_{3}^{-}$concentrations showed NOBs were active and consuming some $\mathrm{NO}_{2}^{-}$. Although it is unlikely that during normal reactor operation (aeration rate $250-750 \mathrm{~L}^{-1}$ ) the aeration rate would suddenly increase to $3000 \mathrm{~L} \mathrm{~h}^{-1}$, high $D O$ could occur due to, for example, a sudden decrease in AOB activity and therefore in oxygen consumption [23]. These experiments show that the $r\left(\mathrm{~N}_{2} \mathrm{O}\right) / r\left(\mathrm{NH}_{4}^{+}\right)$remains a robust signal for process control (Figure 3), even though $\mathrm{N}_{2} \mathrm{O}$ production shifted from the unknown pathway into a nitrifier denitrification-dominated regime. Aeration rate would be reduced in response to online measurements of $\mathrm{N}_{2} \mathrm{O}$ mixing ratio to successfully return the reactor to stable operation.

\subsection{2. $\mathrm{NO}_{2}^{-}$addition under aerobic conditions (normal aeration)}

$\mathrm{NO}_{2}^{-}$was added to the reactor in several experiments to enhance $\mathrm{N}_{2} \mathrm{O}$ production via nitrifier denitrification, as shown in Figure 4. Despite significant addition of $\mathrm{NO}_{2}^{-}$, the concentration of $\mathrm{NO}_{2}^{-}$did not increase in the reactor, showing anammox and/or nitrifier denitrification activity was high. In all cases, the $\delta^{15} \mathrm{~N}^{\text {bulk }}$ changed significantly to approach the $\delta^{15} \mathrm{~N}$ of the added $\mathrm{NaNO}_{2}$ salt (grey dashed line in Figure 4), showing the additional $\mathrm{NO}_{2}^{-}$was consumed and contributed to $\mathrm{N}_{2} \mathrm{O}$ emissions. The fractionation of $\delta^{15} \mathrm{~N}$ during $\mathrm{N}_{2} \mathrm{O}$ production cannot be inferred as almost all $\mathrm{NO}_{2}^{-}$is consistently consumed, thus the effective fractionation is very small.

The net $\mathrm{N}_{2} \mathrm{O}$ production rate and $r\left(\mathrm{~N}_{2} \mathrm{O}\right) / r\left(\mathrm{NH}_{4}^{+}\right)$increased, and the SP decreased 
by between $7 \%$ (cycle $f$, second peak) and $21.5 \%$ (cycle $h$ ) each time $\mathrm{NO}_{2}^{-}$was added ${ }^{3}$. The $\delta^{18} \mathrm{O}$ and SP values show a strong correlation $\left(\mathrm{R}^{2}=0.72\right)$, which suggests minimal influence from O-isotope exchange, which would be expected to alter $\delta^{18} \mathrm{O}$ with no affect on SP. The difference between $\delta^{18} \mathrm{O}$ and SP varies between -7.8 and $20 \%$ with the smallest differences during $\mathrm{NO}_{2}^{-}$addition, which suggests a shift between two dominant $\mathrm{N}_{2} \mathrm{O}$ production pathways, with little influence from confounding factors such as the dependence of fractionation factors on process conditions [5, 72]. During cycle $o$, the $\mathrm{NH}_{4}^{+}$setpoint was raised to $100 \mathrm{mg}-\mathrm{N} \mathrm{L}^{-1}$ to simultaneously enhance $\mathrm{N}_{2} \mathrm{O}$ production via nitrifier denitrification and $\mathrm{NH}_{2} \mathrm{OH}$ oxidation $[69,43]$. The observed $\mathrm{SP}$ change was in the same range as for all other $\mathrm{NO}_{2}^{-}$addition cycles shown in Figure 4, therefore it appears that $\mathrm{NH}_{2} \mathrm{OH}$ oxidation plays a minor role in $\mathrm{N}_{2} \mathrm{O}$ production, in agreement with the results presented in the previous subsections (Sections 3.2 and 3.3.1). The baseline $\mathrm{SP}$ before $\mathrm{NO}_{2}^{-}$addition (black dashed line in Figure 4) was lower in cycles $m$ and $o$ than in cycles $f-i$, which may indicate that AOBs were relatively more active compared to anammox in these cycles, perhaps due to favourable growth conditions - however in the absence of specific microbial activity measurements, the SP differences cannot be definitively explained.

The SP decrease in each case is significantly correlated with the $\mathrm{NO}_{2}^{-}$addition rate (data not shown): Increasing $\mathrm{NO}_{2}^{-}$addition rate results in a lower $\mathrm{SP}$ minimum. This shows that, although $\mathrm{NO}_{2}^{-}$did not build up substantially in the bulk phase of the reactor, heterotrophic or nitrifier denitrification was enhanced following $\mathrm{NO}_{2}^{-}$addition. This suggests a transition between two pathways, in agreement with the strong correlation between $\delta^{18} \mathrm{O}$ and SP. The high SP pathway could either be unknown, or $\mathrm{NH}_{2} \mathrm{OH}$ oxidation with a previously unseen high SP fractionation; the former is more likely as the SP change at high $\mathrm{NH}_{4}^{+}$concentrations discussed in the previous paragraph suggests $\mathrm{NH}_{2} \mathrm{OH}$

\footnotetext{
${ }^{3} \mathrm{SP}$ decrease $=\mathrm{SP}$ during $\mathrm{NO}_{2}^{-}$addition (minima in Figure 4) $-\mathrm{SP}$ before/after addition (dashed line in Figure 4)
} 
oxidation is unimportant overall. An alternative explanation for decreasing SP following $\mathrm{NO}_{2}^{-}$addition is that $\mathrm{NO}_{2}^{-}$inhibits HET activity $[11,3]$, resulting in less reduction of $\mathrm{N}_{2} \mathrm{O}$ by HET and consequently lower SP. However, the highest observed $\mathrm{NO}_{2}^{-}$concentration was $<3 \mathrm{mg}-\mathrm{N} \mathrm{L}^{-1}$ (see Figure 4) while previous studies have observed HET activity at $\mathrm{NO}_{2}^{-}$concentrations up to $50 \mathrm{mg}-\mathrm{N} \mathrm{L}^{-1}[37,1,19]$.

\subsection{3. $\mathrm{NO}_{2}^{-}$addition under anoxic conditions ( $\mathrm{N}_{2}$ purging)}

In cycles $r, z$, and $b b \mathrm{NO}_{2}^{-}$was added to the reactor (Figure 5) and the gas flow was switched to $\mathrm{N}_{2}$, thus $\mathrm{N}_{2} \mathrm{O}$ production via nitrifier denitrification was promoted by excess $\mathrm{NO}_{2}^{-}$until all AOB activity was stopped by anoxic conditions. Cessation of NO emissions shows both AOB and HET activity was very low due to a lack of suitable electron donor compounds, consistent with the initially low HET activity expected given the low organic carbon concentrations in the supernatant liquor $[73,37]$. Continuing $\mathrm{NH}_{4}^{+}$consumption shows that anammox remained active with $\mathrm{N}_{2}$ aeration because $\mathrm{NO}_{2}^{-}$was continuously added.

In cycles $r$ and $z \mathrm{NO}_{2}^{-}$addition began under aerobic conditions and SP dropped by 9 and $15 \%$ respectively, showing that nitrifier denitrification was enhanced by $\mathrm{NO}_{2}^{-}$addition as discussed in the previous subsection (Section 3.3.2; $\mathrm{NO}_{2}^{-}$under aerobic conditions) - this is consistent with nitrifier denitrification being active at much lower organic C concentrations than heterotrophic denitrification [68]. There is a strong correlation between $\delta^{18} \mathrm{O}$ and $\mathrm{SP}\left(\mathrm{R}^{2}=0.53\right)$, and the difference between $\delta^{18} \mathrm{O}$ and SP $(0.2$ to $16 \%$ ) is lowest when $\mathrm{NO}_{2}^{-}$is added before anoxia is introduced. This is also in agreement with the results of the previous subsection and again suggests a shift between two dominant pathways with little influence from dependence of fractionation factors on varying conditions or O-isotope exchange $[5,72]$. When the air flow was switched to $\mathrm{N}_{2}$, however, SP increased immediately by $\sim 9 \%$ as $\mathrm{N}_{2} \mathrm{O}$ production by $\mathrm{AOB}$ ceased [73]. In cycle $b b, \mathrm{NO}_{2}^{-}$ addition and $\mathrm{N}_{2}$ aeration were started simultaneously and SP increased significantly by 
$7 \%(\mathrm{p}<0.001)$ to reach the highest value measured over the whole experimental period, $+45.9 \%$.

The simultaneous decrease in $\delta^{15} \mathrm{~N}^{\text {bulk }}$ following $\mathrm{NO}_{2}^{-}$addition shows consumption of the isotopically-light $\mathrm{NO}_{2}^{-}$substrate (supplementary material Section $\mathrm{S} 1.2$ ); however unlike SP, $\delta^{15} \mathrm{~N}^{\text {bulk }}$ remains lower with $\mathrm{N}_{2}$ aeration, particularly in cycle $b b$, reflecting the low $\delta^{15} \mathrm{~N}$ of the added salt relative to the supernatant liquor and showing that the added $\mathrm{NO}_{2}^{-}$substrate is being used to produce $\mathrm{N}_{2} \mathrm{O}$ - even though reactor conditions $\left(\mathrm{N}_{2}\right.$ aeration; no $\mathrm{O}_{2}$ ) suggest nitrifier denitrification will not be occurring. $\mathrm{N}_{2} \mathrm{O}$ production by HET also involves $\mathrm{NO}_{2}^{-}$reduction [35] and agrees with the low $\delta^{15} \mathrm{~N}^{\text {bulk }}$ discrimination between the added $\mathrm{NO}_{2}^{-}$and the observed $\mathrm{N}_{2} \mathrm{O}$ [45]; however the $\mathrm{N}_{2} \mathrm{O}$ produced by $\mathrm{HET}$ has low $\mathrm{SP}(\sim 0 \%$ o $[57,70])$. This pathway can therefore not explain the results, unless $>90 \%$ of the $\mathrm{N}_{2} \mathrm{O}$ is subsequently reduced to $\mathrm{N}_{2}$ by HET (using Rayleigh fractionation equations as described in Section 3.2). This is not consistent with low COD in the system, or with the relatively high $\mathrm{N}_{2} \mathrm{O}$ emissions, particularly during cycle $b b$. Furthermore, $\mathrm{NO}_{3}^{-}$ production is close to the $11 \%$ expected from anammox and therefore not consistent with strong HET activity (Figure 5).

Both microbial and inorganic production of $\mathrm{N}_{2} \mathrm{O}$ from $\mathrm{NH}_{2} \mathrm{OH}$ have been observed to produce $\mathrm{SP}$ values of $29-36 \%$ o $[61,57,15,45,69,18,71]$; $\mathrm{SP}$ of inorganic $\mathrm{N}_{2} \mathrm{O}$ production via $\mathrm{NO}_{2}^{-}$reduction by $\mathrm{Fe}^{2+}$ has not been measured and can therefore not be assessed.

A recent study by Yang et al. [72] considering fungal nitric oxide reductase (P450nor) suggests that SP may not always be a conservative tracer of reaction pathways, in contrast to pure culture studies on fungal denitrification by Sutka et al. [56] and more recently Rohe et al. [52], which show highly constant SP values for a particular species, with some variation between species. Yang et al. [72] suggest that the variation in SP (15-29\%) observed in their study was due to non-steady state conditions regarding NO supply and consumption and cell growth conditions; however non-steady state conditions resulted in lower, not higher, SP in their study. It is possible that high SP in the present experiments 
is due to $\mathrm{N}_{2} \mathrm{O}$ production from $\mathrm{NH}_{2} \mathrm{OH}$ oxidation when conditions are far from steady state; another possibility is that previous attempts to measure the $\mathrm{SP}$ of the $\mathrm{NH}_{2} \mathrm{OH}$ pathway were contaminated by low $\mathrm{SP}-\mathrm{N}_{2} \mathrm{O}$ from inorganic or microbial $\mathrm{N}_{2} \mathrm{O}$ production by denitrification. In the latter case, the present study would need to have significantly less $\mathrm{N}_{2} \mathrm{O}$ from denitrification than all previous studies, to make the 'true' high $\mathrm{SP}$ of the $\mathrm{NH}_{2} \mathrm{OH}$ pathway visible, which is unlikely given that this study uses a mixed culture and real supernatant liquor rather than a well-constrained pure culture and growth medium. Additionally, results in Sections 3.2, 3.3.1 and 3.3.2 suggest the $\mathrm{NH}_{2} \mathrm{OH}$ pathway is not important in this system, consistent with previous results [43, 21]. However, these two explanations cannot be definitively discounted based on the available evidence.

The experiments testing $\mathrm{NO}_{2}^{-}$addition under $\mathrm{N}_{2}$ aeration therefore may suggest, in agreement with the other experimental results as discussed in the previous sections, that an anoxic pathway is producing $\mathrm{N}_{2} \mathrm{O}$ with high $\mathrm{SP}\left(\geq 45 \%\right.$ ), enhanced by $\mathrm{NO}_{2}^{-}$addition and anoxic conditions - and therefore possibly associated with anammox activity. The unknown pathway may have a low level of isotopic discrimination for $\delta^{15} \mathrm{~N}^{\text {bulk }}$, given the close agreement between the $\delta^{15} \mathrm{~N}$ of added $\mathrm{NO}_{2}^{-}$and $\delta^{15} \mathrm{~N}^{\mathrm{bulk}}$ of $\mathrm{N}_{2} \mathrm{O}$ in cycles $z$ and $b b$ however $\delta^{15} \mathrm{~N}$ discrimination can be highly variable, and in addition it is unclear if all of the $\mathrm{N}$ in $\mathrm{N}_{2} \mathrm{O}$ derives from $\mathrm{NO}_{2}^{-}$.

\subsubsection{Addition of $\mathrm{NH}_{2} \mathrm{OH}$}

In cycle $y, \mathrm{NH}_{2} \mathrm{OH}$ was continuously added at a rate of $20-80 \mathrm{mg}-\mathrm{N} / \mathrm{min}$ for a total of 204 minutes (total addition $=9.3 \mathrm{~g}-\mathrm{N} \approx 23 \mathrm{mg}-\mathrm{N} \mathrm{L}^{-1}$ ) to promote $\mathrm{N}_{2} \mathrm{O}$ production via $\mathrm{NH}_{2} \mathrm{OH}$ oxidation (results shown in supplementary infomation, Figure $\mathrm{S} 6$ ). The $\mathrm{N}_{2} \mathrm{O}$ production rate increased twofold when $\mathrm{NH}_{2} \mathrm{OH}$ was added. The $\mathrm{SP}$ of emitted $\mathrm{N}_{2} \mathrm{O}$ also increased significantly, from $34.4 \pm 1.1 \%$ o to $41.3 \pm 1.8 \%$ ( $(\Delta \mathrm{SP}=6.9 \pm 2.1 ; \mathrm{p}<0.001)$. The final SP of $41.3 \%$ is $5 \%$ higher than the highest values reported in the literature for $\mathrm{NH}_{2} \mathrm{OH}$ oxidation $[15,57]$ (see Table 1). 
As in the previous experiments, we can consider several possibilities for these high values: i) significant $\mathrm{N}_{2} \mathrm{O}$ reduction by HET, ii) an unknown inorganic or microbial $\mathrm{N}_{2} \mathrm{O}$ production pathway with a much higher end-member $\mathrm{SP}$, where $\mathrm{NH}_{2} \mathrm{OH}$ is somehow involved either directly, or indirectly via the formation of intermediates, or iii) previous measurements of $\mathrm{NH}_{2} \mathrm{OH}$ characteristic $\mathrm{SP}$ are too low due to 'contaminant' $\mathrm{N}_{2} \mathrm{O}$ from denitrification, or $\mathrm{SP}$ of $\mathrm{N}_{2} \mathrm{O}$ from $\mathrm{NH}_{2} \mathrm{OH}$ is higher when growth conditions are not at steady state [72]. HET reduction would need to remove $>50-70 \%$ of $\mathrm{N}_{2} \mathrm{O}$ to achieve the observed SP of $41 \%$ [46, 22, 62] produced following $\mathrm{NH}_{2} \mathrm{OH}$ addition, calculated using Rayleigh fractionation as described in Section 3.2 [38], which is very unlikely given the low organic carbon content. The SP fractionation during $\mathrm{N}_{2} \mathrm{O}$ reduction may vary depending on conditions such as substrate availability; however the above simulations are based on enrichment factors from four different studies under widely varying environmental conditions $\left(\epsilon_{\mathrm{SP}}=-2.9\right.$ to $-8.2 \%$, see Table S2) and are therefore considered robust. Such high levels of reduction are also inconsistent with the observed increase in $\mathrm{N}_{2} \mathrm{O}$ production rate following $\mathrm{NH}_{2} \mathrm{OH}$ addition. $\mathrm{SP}$ of $\mathrm{N}_{2} \mathrm{O}$ produced from abiotic reduction of $\mathrm{NO}_{2}^{-}$by $\mathrm{Fe}^{2+}[25]$ has been measured by only one study, and found to be in the range of -13.3 to $+22.6 \%$ [53]; thus this pathway is unlikely to explain our observations. $\mathrm{SP}$ of $\mathrm{N}_{2} \mathrm{O}$ produced from the inorganic oxidation of $\mathrm{NH}_{2} \mathrm{OH}$ is in a very narrow range of 34-35\% , with little sensitivity to process conditions [18]. As discussed in the previous subsection, incorrect or varying $\mathrm{SP}$ values for microbial $\mathrm{N}_{2} \mathrm{O}$ production via $\mathrm{NH}_{2} \mathrm{OH}$ oxidation are unlikely given the literature but cannot be discounted. An unknown microbial pathway with high SP involving $\mathrm{NH}_{2} \mathrm{OH}$ may be the best explanation for the results, although no previous study has shown clear evidence of such a pathway $[27,36]$.

\subsection{Implications for our understanding of $\mathrm{N}_{2} \mathrm{O}$ production}

The online isotopic measurements of $\mathrm{N}_{2} \mathrm{O}$ produced in a combined $\mathrm{PN}$-anammox reactor provided a rich dataset that revealed unexpected results regarding $\mathrm{N}_{2} \mathrm{O}$ production 
pathways. The results of this study showed that nitrifier denitrification is responsible for $\mathrm{N}_{2} \mathrm{O}$ emission peaks at high $\mathrm{NH}_{4}^{+}$concentrations, when $\mathrm{AOB}$ and anammox activities are not optimally balanced (eg. when the aeration rate or the $D O$ is too high; see Section 3.3.1). However, consistently high SP observed during normal operation (Figures 2, $\mathrm{S} 1$ and $\mathrm{S} 4$ ) show that either $\mathrm{N}_{2} \mathrm{O}$ production also occurs via an unknown pathway with high SP, HET activity and thus $\mathrm{N}_{2} \mathrm{O}$ reduction is much stronger than expected, or fractionation factors reported in previous studies (Table 1) cover an incomplete range. $\mathrm{N}_{2} \mathrm{O}$ emissions of this type, which cannot be explained within our current understanding - low $\mathrm{N}_{2} \mathrm{O}$ production rate and high SP - accounted for $>75 \%$ of the total $\mathrm{N}_{2} \mathrm{O}$ production ${ }^{4}$ over the entire experimental period, and close to $100 \%$ of emissions during normal operating conditions. A number of experimental pertubations were applied to the system to test these hypotheses.

The results of these experiments are most consistent with the hypothesis that high SP is due to an unknown $\mathrm{N}_{2} \mathrm{O}$ production pathway (Table 2) - although the other proposed hypotheses cannot be dismissed. HET reduction would need to consume $>90 \%$ of $\mathrm{N}_{2} \mathrm{O}$ to achieve the highest SP value of $45.9 \%$ observed during the entire experimental period (Section 3.3.3), and $>70 \%$ of $\mathrm{N}_{2} \mathrm{O}$ to reach the maximum 'baseline' SP value of $39.7 \%$ (Section 3.2), calculated using Rayleigh fractionation as described in Section 3.2 [38]. This level of reduction is unlikely due to low COD concentrations and observed N transformation rates - eg. high $\mathrm{N}_{2} \mathrm{O}$ production rates, and $\sim 10 \% \mathrm{NO}_{3}^{-}$production relative to $\mathrm{NH}_{4}^{+}$consumption - however it cannot be entirely ruled out without isotopic tracer experiments. $\mathrm{O}$ isotope exchange could explain why the slope of SP to $\delta^{18} \mathrm{O}$ does not agree with $\mathrm{N}_{2} \mathrm{O}$ reduction during baseline experiments (Figure 2) as discussed in Section 3.2, but an important role of heterotrophic $\mathrm{N}_{2} \mathrm{O}$ reduction is generally not consistent with our other experimental results, particularly during $\mathrm{NO}_{2}^{-}$addition (Sections 3.3.2 and 3.3.3).

Highly varying $\mathrm{SP}$ fractionation for the $\mathrm{NH}_{2} \mathrm{OH}$ pathway is unlikely given the relatively tight range of 29-36.3\% measured in numerous previous studies considering a variety of 
pathways, including inorganic, pure culture, and mixed culture $\mathrm{N}_{2} \mathrm{O}$ production ([57, 15]; [62] and [45] and references therein; $[69,18,71])$. If an unknown pathway is occurring in the reactor, it would be characterised by production of $\mathrm{N}_{2} \mathrm{O}$ with high SP $(\geq 45 \%$ - the maximum SP observed, during $\mathrm{NO}_{2}^{-}$addition under anoxic conditions) and appears to be associated with anammox metabolism directly or indirectly as an associated inorganic pathway, possibly involving $\mathrm{NH}_{2} \mathrm{OH}$. Further experimentation is needed to confirm the existence of this pathway and gain a definitive understanding of $\mathrm{N}_{2} \mathrm{O}$ production in PNanammox systems. The new questions regarding the nitrogen cycle in a PN-anammox reactor raised by the results of this study are shown schematically in Figure 6 .

The results of this study show that online $\mathrm{N}_{2} \mathrm{O}$ monitoring is an ideal method for process control in a combined, continuously-fed $\mathrm{PN}$-anammox reactor, extending the current set of available online parameters (eg. $\mathrm{pH}$, conductivity, $\mathrm{NH}_{4}^{+}, \mathrm{NO}_{3}^{-}$, aeration rate). During stable operation $\mathrm{N}_{2} \mathrm{O}$ emissions are within the range required for anammox systems to have a positive energy balance compared to traditional nitrification-denitrification wastewater treatment processes. When $D O$ or $\mathrm{NO}_{2}^{-}$increase due to eg. changes in AOB or anammox activity, $\mathrm{N}_{2} \mathrm{O}$ emissions via nitrifier denitrification are enhanced; thus aeration can be decreased in response to high measured offgas $\mathrm{N}_{2} \mathrm{O}$ mixing ratio to keep the reactor in a stable state while simultaneously minimizing GHG emissions.

\section{Conclusions}

This study uses online measurements of $\mathrm{N}_{2} \mathrm{O}$ concentration and isotopic composition to understand $\mathrm{N}_{2} \mathrm{O}$ production pathways under a variety of conditions, and assess the use of $\mathrm{N}_{2} \mathrm{O}$ measurements for process control in a single-stage PN-anammox reactor. The main conclusions of this study are:

\footnotetext{
${ }^{4}$ Estimated as $\mathrm{N}_{2} \mathrm{O}$ production rate $\times$ time where $\mathrm{SP}>33 \%$, compared to production rate $\times$ time where $\mathrm{SP}<33 \%$.
} 
- Online measurements of $\mathrm{N}_{2} \mathrm{O}$ offgas mixing ratio are an ideal method to balance activity of AOBs and anammox, to maintain process stability in a single-stage PNanammox reactor.

- High isotopic SP when $\mathrm{N}_{2} \mathrm{O}$ emissions are relatively low during optimal operation indicates that our current understanding of $\mathrm{N}_{2} \mathrm{O}$ production and isotopic fractionation is incomplete, and may suggest the existence of an unknown $\mathrm{N}_{2} \mathrm{O}$ production pathway associated with anammox metabolism.

- When $\mathrm{NH}_{4}^{+}$or $D O$ are elevated in the reactor, $\mathrm{N}_{2} \mathrm{O}$ production by nitrifier denitrification is enhanced. $\mathrm{N}_{2} \mathrm{O}$ production via $\mathrm{NH}_{2} \mathrm{OH}$ oxidation is relatively unimportant in the reactor under all conditions.

\section{Acknowledgments}

We thank Thomas Kuhn, Moritz Lehmann and Caitlin Frame from the University of Basel for measuring the $\delta^{15} \mathrm{~N}$ of $\mathrm{NaNO}_{2}$ and $\mathrm{NH}_{2} \mathrm{OHCl}$ salts and Beat Beyeler from WWTP Zürich Werdhölzli for providing the supernatant liquor. Instrumental developments at Empa were funded by the State Secretariat for Education and Research (SER) within COST Action ES0806 and the Swiss National Science Foundation (SNSF). Eliza Harris was supported by the European Union's Seventh Framework Programme for research, technological development and demonstration under grant agreement no. 2010267161.

The supplementary information file contains Section S1: Materials and Methods, Figures S1-S6 and Table S1-S2. 


\section{References}

[1] Abdul-Wahab, S. a., Worthing, M. a., Al-Maamari, S., Aug. 2005. Mineralogy of atmospheric suspended dust in three indoor and one outdoor location in Oman. Environmental monitoring and assessment 107 (1-3), 313-27.

URL http://www.ncbi.nlm.nih.gov/pubmed/16418920

[2] Arp, D. J., Stein, L. Y., 2003. Metabolism of Inorganic N Compounds by AmmoniaOxidizing Bacteria. Critical Reviews in Biochemistry and Molecular Biology 38, 471485.

[3] Baumann, B., Snozzi, M., Van Der Meer, J., a.J.B. Zehnder, Aug. 1997. Development of stable denitrifying cultures during repeated aerobic-anaerobic transient periods. Water Research 31 (8), 1947-1954.

URL http://linkinghub.elsevier.com/retrieve/pii/S0043135497000535

[4] Bogner, J., Ahmed, M. A., Diaz, C., Faaij, A., Gao, Q., Hashimoto, S., Mareckova, K., Pipatti, R., Zhang, T., 2007. Waste Management. In: Davidson, O. R., Bosch, P. R., Dave, R., Meyer, L. A. (Eds.), Climate Change 2007: Mitigation. Contribution of working group III to the Fourth Assessment Report of the Intergovernmental Panel on Climate Change. Cambridge University Press, Cambridge, pp. 585-618.

[5] Buchwald, C., Casciotti, K. L., 2010. Oxygen isotopic fractionation and exchange during bacterial nitrite oxidation. Limnology and Oceanography 55 (3), 1064-1074. URL http://doi.wiley.com/10.4319/1o.2010.55.3.1064

[6] Bürgmann, H., Jenni, S., Vazquez, F., Udert, K. M., Sep. 2011. Regime shift and microbial dynamics in a sequencing batch reactor for nitrification and anammox treatment of urine. Applied and environmental microbiology 77 (17), 5897-907. URL http://www . pubmedcentral.nih.gov/articlerender.fcgi?artid=3165423\&tool=pmcentr 
[7] Casciotti, K. L., Sigman, D. M., Hastings, M. G., Böhlke, J. K., Hilkert, a., 2002. Measurement of the oxygen isotopic composition of nitrate in seawater and freshwater using the denitrifier method. Analytical Chemistry 74 (19), 4905-4912.

[8] Chandran, K., Stein, L. Y., Klotz, M. G., van Loosdrecht, M. C. M., Dec. 2011. Nitrous oxide production by lithotrophic ammonia-oxidizing bacteria and implications for engineered nitrogen-removal systems. Biochemical Society Transactions 39 (6), $1832-7$.

[9] Crutzen, P. J., 1970. The influence of nitrogen oxides on the atmospheric ozone content. Q.J.R. Meteorol. Soc. 96 (408), 320-325.

URL http://dx.doi.org/10.1002/qj.49709640815

[10] Dapena-Mora, A., Fernández, I., Campos, J., Mosquera-Corral, A., Méndez, R., Jetten, M., Mar. 2007. Evaluation of activity and inhibition effects on Anammox process by batch tests based on the nitrogen gas production. Enzyme and Microbial Technology 40 (4), 859-865.

URL http://linkinghub.elsevier.com/retrieve/pii/S0141022906003450

[11] Ferguson, S. J., 1995. Denitrification and its control. Antonie van Leeuwenhoek 66, $89-110$.

[12] Fernández, I., Vázquez-Padín, J., Mosquera-Corral, A., Campos, J., Méndez, R., Dec. 2008. Biofilm and granular systems to improve Anammox biomass retention. Biochemical Engineering Journal 42 (3), 308-313.

[13] Firestone, M., Davidson, E., 1989. Microbiological basis of NO and N2O production and consumption in soil. In: Andreae, M.O. and Schimel, D. (Ed.), Exchange of trace gases between terrestrial ecosystems and the atmosphere. Wiley, New York, pp. 7-21. 
[14] Forster, P. M., Ramaswamy, V., Artaxo, P., Berntsen, T. K., Betts, R., Fahey, D. W., Haywood, J., Lean, J., Lowe, D. C., Myrhe, G., Nganga, J., Prinn, R., Raga, G., Schulz, M., Van Dorland, R., 2007. Changes in Atmospheric Constituents and in Radiative Forcing. In: Climate Change 2007: The physical science basis. Contribution of the working group I to the Fourth Assessment Report of the Intergovernmental Panel on Climate Change.

[15] Frame, C. H., Casciotti, K. L., Sep. 2010. Biogeochemical controls and isotopic signatures of nitrous oxide production by a marine ammonia-oxidizing bacterium. Biogeosciences 7 (9), 2695-2709.

URL http: //www. biogeosciences.net/7/2695/2010/

[16] Gilbert, E. M., Müller, E., Horn, H., Lackner, S., Oct. 2013. Microbial activity of suspended biomass from a nitritation-anammox SBR in dependence of operational condition and size fraction. Applied Microbiology and Biotechnology 97 (19), 8795804.

[17] Harris, E., Nelson, D. D., Olszewski, W., Zahniser, M., Potter, K. E., McManus, B. J., Whitehill, A., Prinn, R. G., Ono, S., Feb. 2014. Development of a spectroscopic technique for continuous online monitoring of oxygen and site-specific nitrogen isotopic composition of atmospheric nitrous oxide. Analytical chemistry 86 (3), 1726-34.

URL http://www.ncbi.nlm.nih.gov/pubmed/24328290

[18] Heil, J., Wolf, B., Brueggemann, N., Emmenegger, L., Tuzson, B., Vereecken, H., Mohn, J., 2014. Site-specific 15N signatures of abiotically-produced N2O. Geochimica et Cosmochimica Acta 139, 72-82.

[19] Hosseini, M., Sahraei, E., Khoshfetrat, a. B., Ebrahimi, S., Dec. 2013. Nitrate and Nitrite Removal Using a Continuous Heterotrophic Denitrifying Granular Sludge Biore- 
actor. Chemical Engineering \& Technology 36 (12), 2101-2107.

URL http://doi.wiley.com/10.1002/ceat. 201300254

[20] Imajo, U., Tokutomi, T., Furukawa, K., Jan. 2004. Granulation of Anammox microorganisms in up-flow reactors. Water Science and Technology 49 (5-6), 155-63.

[21] Ishii, S., Song, Y., Rathnayake, L., Tumendelger, A., Satoh, H., Toyoda, S., Yoshida, N., Okabe, S., Mar. 2014. Identification of key N2O production pathways in aerobic partial nitrifying granules. Environmental Microbiology.

[22] Jinuntuya-Nortman, M., Sutka, R. L., Ostrom, P. H., Gandhi, H., Ostrom, N. E., Sep. 2008. Isotopologue fractionation during microbial reduction of N2O within soil mesocosms as a function of water-filled pore space. Soil Biology and Biochemistry $40(9), 2273-2280$.

URL http://linkinghub.elsevier.com/retrieve/pii/S0038071708001582

[23] Joss, A., Derlon, N., Cyprien, C., Burger, S., Szivak, I., Traber, J., Siegrist, H., Morgenroth, E., Nov. 2011. Combined nitritation-anammox: Advances in understanding process stability. Environmental Science \& Technology 45 (22), 9735-42.

[24] Joss, A., Salzgeber, D., Eugster, J., König, R., Rottermann, K., Burger, S., Fabijan, P., Leumann, S., Mohn, J., Siegrist, H., Jul. 2009. Full-scale nitrogen removal from digester liquid with partial nitritation and anammox in one SBR. Environmental Science \& Technology 43 (14), 5301-6.

[25] Kampschreur, M. J., Kleerebezem, R., de Vet, W. W. J. M., van Loosdrecht, M. C. M., Nov. 2011. Reduced iron induced nitric oxide and nitrous oxide emission. Water research 45 (18), 5945-52.

[26] Kampschreur, M. J., Poldermans, R., Kleerebezem, R., van der Star, W. R. L., Haarhuis, R., Abma, W. R., Jetten, M. S. M., van Loosdrecht, M. C. M., Jan. 2009. 
Emission of nitrous oxide and nitric oxide from a full-scale single-stage nitritationanammox reactor. Water Science \& Technology 60 (12), 3211-7.

[27] Kartal, B., Maalcke, W. J., de Almeida, N. M., Cirpus, I., Gloerich, J., Geerts, W., Op den Camp, H. J. M., Harhangi, H. R., Janssen-Megens, E. M., Francoijs, K.J., Stunnenberg, H. G., Keltjens, J. T., Jetten, M. S. M., Strous, M., Nov. 2011. Molecular mechanism of anaerobic ammonium oxidation. Nature 479 (7371), 127-30.

[28] Koerner, H., Zumft, W. G., 1989. Expression of Denitrification Enzymes in Response to the Dissolved Oxygen Level and Respiratory Substrate in Continuous Culture of Pseudomonas stutzeri. Applied and Environmental Microbiology 55 (7), 1670-1676.

[29] Kool, D. M., Mueller, C., Wrage, N., Oenema, O., van Groeningen, J. W., 2009. Oxygen exchange between nitrogen oxides and $\mathrm{H} 2 \mathrm{O}$ can occur during nitrifier pathways. Soil Biology and Biochemistry 41, 1632-1641.

[30] Kool, D. M., Wrage, N., Oenema, O., Dolfing, J., Groenigen, J. W. V., 2007. Oxygen exchange between (de)nitrification intermediates and $\mathrm{H} 2 \mathrm{O}$ and its implications for source determination of NO3- and N2O: a review. Rapid Communications In Mass Spectrometry 21, 3569-3578.

[31] Köster, J. R., Well, R., Dittert, K., Giesemann, A., Lewicka-Szczebak, D., Mühling, K.-H., Herrmann, A., Lammel, J., Senbayram, M., Nov. 2013. Soil denitrification potential and its influence on $\mathrm{N} 2 \mathrm{O}$ reduction and $\mathrm{N} 2 \mathrm{O}$ isotopomer ratios. Rapid communications in mass spectrometry : RCM 27 (21), 2363-73.

[32] Köster, J. R., Well, R., Tuzson, B., Bol, R., Dittert, K., Giesemann, A., Emmenegger, L., Manninen, A., Cárdenas, L., Mohn, J., Jan. 2013. Novel laser spectroscopic technique for continuous analysis of $\mathrm{N} 2 \mathrm{O}$ isotopomers-application and intercomparison with isotope ratio mass spectrometry. Rapid communications in mass spectrometry 
: RCM 27 (1), 216-22.

URL http://www.ncbi.nlm.nih.gov/pubmed/23239336

[33] Kuypers, M. M. M., Lavik, G., Woebken, D., Schmid, M., Fuchs, B. M., Amann, R., Jø rgensen, B. B., Jetten, M. S. M., May 2005. Massive nitrogen loss from the Benguela upwelling system through anaerobic ammonium oxidation. Proceedings of the National Academy of Sciences of the United States of America 102 (18), 6478-83.

[34] Kuypers, M. M. M., Sliekers, A. O., Lavik, G., Schmid, M., Jorgensen, B. B., Kuenen, J., Sinninghe Damste, J. S., Strous, M., Jetten, M. S. M., 2003. Anaerobic ammonium oxidation by anammox bacteria in the Black Sea. Nature 422, 608-611.

[35] Law, Y., Ye, L., Pan, Y., Yuan, Z., May 2012. Nitrous oxide emissions from wastewater treatment processes. Philosophical transactions of the Royal Society of London. Series B, Biological sciences 367 (1593), 1265-77.

URL http://www . pubmedcentral.nih.gov/articlerender.fcgi?artid=3306625\&tool=pmcentr

[36] Lotti, T., Kleerebezem, R., Lubello, C., van Loosdrecht, M., Apr. 2014. Physiological and kinetic characterization of a suspended cell anammox culture. Water Research $60,1-14$.

[37] Lu, H., Chandran, K., Jun. 2010. Factors promoting emissions of nitrous oxide and nitric oxide from denitrifying sequencing batch reactors operated with methanol and ethanol as electron donors. Biotechnology and bioengineering 106 (3), 390-8.

URL http://www.ncbi.nlm.nih.gov/pubmed/20178110

[38] Mariotti, A., Germon, J. C., Hubert, P., Kaiser, P., Letolle, R., Tardieux, A., Tardieux, P., 1981. Experimental-determination of Nitrogen Kinetic Isotope Fractionation - Some Principles - Illustration For the Denitrification and Nitrification Processes. Plant and Soil 62 (3), 413-430. 
[39] Mohn, J., Guggenheim, C., Tuzson, B., Vollmer, M. K., Toyoda, S., Yoshida, N., Emmenegger, L., May 2010. A liquid nitrogen-free preconcentration unit for measurements of ambient N2O isotopomers by QCLAS. Atmospheric Measurement Techniques 3 (3), 609-618.

[40] Mohn, J., Tuzson, B., Manninen, A., Yoshida, N., Toyoda, S., Brand, W. A., Emmenegger, L., 2012. Site selective real-time measurements of atmospheric N2O isotopomers by laser spectroscopy. Atmospheric Measurement Techniques 5, 16011609.

[41] Mohn, J., Wolf, B., Toyoda, S., Li, C.-T., Liang, M.-C., Brüggemann, N., Wissel, H., Steiker, A. E., Dyckman, J., Szwec, L., Ostrom, N. E., Casciotti, K., Forbes, M., Giesemann, A., Well, R., Doucett, R. R., Yarnes, C. T., Ridley, A. R., Kaiser, J., Yoshida, N., 2014. Interlaboratory assessment of nitrous oxide isotopomer analysis by isotope ratio mass spectrometry and laser spectroscopy: Current status and perspectives. Rapid Communications In Mass Spectrometry 28, 1995-2007.

[42] Mulder, A., Graaf, A., Robertson, L., Kuenen, J., Mar. 1995. Anaerobic ammonium oxidation discovered in a denitrifying fluidized bed reactor. FEMS Microbiology Ecology $16(3), 177-184$.

[43] Ni, B.-J., Peng, L., Law, Y., Guo, J., Yuan, Z., Feb. 2014. Modeling of Nitrous Oxide Production by Autotrophic Ammonia-Oxidizing Bacteria with Multiple Production Pathways. Environmental Science \& Technology 48, 3916-3924.

[44] Okabe, S., Oshiki, M., Takahashi, Y., Satoh, H., Dec. 2011. N2O emission from a partial nitrification-anammox process and identification of a key biological process of N2O emission from anammox granules. Water research 45 (19), 6461-70.

[45] Ostrom, N. E., Ostrom, P. H., 2011. The Isotopomers of Nitrous Oxide: Analytical 
Considerations and Applications to the Resolution of Microbial Production Pathways. In: Baskaran, M. (Ed.), Handbook of Environmental Isotope Geochemistry. Springer Berlin Heidelberg, Berlin, Heidelberg, Ch. 23, pp. 453-476.

URL http://link.springer.com/10.1007/978-3-642-10637-8

[46] Ostrom, N. E., Pitt, A., Sutka, R., Ostrom, P. H., Grandy, A. S., Huizinga, K. M., Robertson, G. P., Apr. 2007. Isotopologue effects during N2O reduction in soils and in pure cultures of denitrifiers. Journal of Geophysical Research - Biogeosciences 112 (G2), G02005.

[47] Park, S., Perez, T., Boering, K. A., Trumbore, S. E., Gil, J., Marquina, S., Tyler, S. C., Jan. 2011. Can N2O stable isotopes and isotopomers be useful tools to characterize sources and microbial pathways of $\mathrm{N} 2 \mathrm{O}$ production and consumption in tropical soils? Global Biogeochemical Cycles 25, GB1001.

[48] Perez-Garcia, O., Villas-Boas, S. G., Swift, S., Chandran, K., Singhal, N., May 2014. Clarifying the regulation of $\mathrm{NO} / \mathrm{N} 2 \mathrm{O}$ production in Nitrosomonas europaea during anoxic-oxic transition via flux balance analysis of a metabolic network model. Water research 60C, 267-277.

URL http://www.ncbi.nlm.nih.gov/pubmed/24862955

[49] Rathnayake, R. M. L. D., Song, Y., Tumendelger, a., Oshiki, M., Ishii, S., Satoh, H., Toyoda, S., Yoshida, N., Okabe, S., Dec. 2013. Source identification of nitrous oxide on autotrophic partial nitrification in a granular sludge reactor. Water research 47 (19), 7078-86.

URL http://www.ncbi.nlm.nih.gov/pubmed/24200002

[50] Ravishankara, A. R., Daniel, J. S., Portmann, R. W., Oct. 2009. Nitrous Oxide (N2O): The Dominant Ozone-Depleting Substance Emitted in the 21st Century. Science 326 (5949), 123-125. 
[51] Rodriguez-Caballero, a., Pijuan, M., Jun. 2013. N2O and NO emissions from a partial nitrification sequencing batch reactor: exploring dynamics, sources and minimization mechanisms. Water research 47 (9), 3131-40.

URL http://www.ncbi.nlm.nih.gov/pubmed/23561498

[52] Rohe, L., Anderson, T. H., Braker, G., Flessa, H., Giesemann, A., Lewicka-Szczebak, D., Wrage, N., Well, R., 2014. Dual Isotope And Isotopomer Signatures Of Nitrous Oxide From Fungal Denitrification - A Pure Culture Study. Rapid Communications In Mass Spectrometry 28 (17), 1893-1903.

[53] Samarkin, V. a., Madigan, M. T., Bowles, M. W., Casciotti, K. L., Priscu, J. C., McKay, C. P., Joye, S. B., 2010. Abiotic nitrous oxide emission from the hypersaline Don Juan Pond in Antarctica. Nature Geoscience 3 (5), 341-344.

URL http://dx.doi.org/10.1038/ngeo847

[54] Siegrist, H., Salzgeber, D., Eugster, J., Joss, A., Jan. 2008. Anammox brings WWTP closer to energy autarky due to increased biogas production and reduced aeration energy for N-removal. Water Science and Technology 57 (3), 383-8.

[55] Strous, M., Van Gerven, E., Zheng, P., Kuenen, J. G., Jetten, M. S., Aug. 1997. Ammonium removal from concentrated waste streams with the anaerobic ammonium oxidation (Anammox) process in different reactor configurations. Water Research 31 (8), 1955-1962.

URL http://linkinghub.elsevier.com/retrieve/pii/S0043135497000559

[56] Sutka, R. L., Adams, G. C., Ostrom, N. E., Ostrom, P. H., 2008. Isotopologue fractionation during $\mathrm{N} 2 \mathrm{O}$ production by fungal denitrification. Rapid communications in mass spectrometry 22, 3989-3996.

[57] Sutka, R. L., Ostrom, N. E., Ostrom, P. H., Breznak, J. A., Gandhi, H., Pitt, A. J., Li, F., Jan. 2006. Distinguishing nitrous oxide production from nitrification and 
denitrification on the basis of isotopomer abundances. Applied and Environmental Microbiology 72 (1), 638-644.

[58] Sutka, R. L., Ostrom, N. E., Ostrom, P. H., Gandhi, H., Breznak, J. A., Jan. 2003. Nitrogen isotopomer site preference of $\mathrm{N} 2 \mathrm{O}$ produced by Nitrosomonas europaea and Methylococcus capsulatus Bath. Rapid Communications in Mass Spectrometry $17(7), 738-45$.

[59] Sutka, R. L., Ostrom, N. E., Ostrom, P. H., Gandhi, H., Breznak, J. A., Jun. 2004. Erratum: Nitrogen isotopomer site preference of N2O produced by Nitrosomonas europaea and Methylococcus capsulatus Bath. Rapid Communications in Mass Spectrometry 18 (12), 1411-1412.

[60] Thamdrup, B., Dalsgaard, T., 2002. Production of N2 through Anaerobic Ammonium Oxidation Coupled to Nitrate Reduction in Marine Sediments. Applied and Environmental Microbiology 68 (3), 1312-1318.

[61] Toyoda, S., Mutobe, H., Yamagishi, H., Yoshida, N., Tanji, Y., Aug. 2005. Fractionation of $\mathrm{N} 2 \mathrm{O}$ isotopomers during production by denitrifier. Soil Biology and Biochemistry 37 (8), 1535-1545.

[62] Toyoda, S., Suzuki, Y., Hattori, S., Yamada, K., Fujii, A., Yoshida, N., Kouno, R., Murayama, K., Shiomi, H., Feb. 2011. Isotopomer Analysis of Production and Consumption Mechanisms of N2O and CH4 in an Advanced Wastewater Treatment System. Environmental Science \& Technology 45 (3), 917-922.

[63] Toyoda, S., Yano, M., Nishimura, S.-i., Akiyama, H., Hayakawa, A., Koba, K., Sudo, S., Yagi, K., Makabe, A., Tobari, Y., Ogawa, N. O., Ohkouchi, N., Yamada, K., Yoshida, N., May 2011. Characterization and production and consumption processes of $\mathrm{N} 2 \mathrm{O}$ emitted from temperate agricultural soils determined via isotopomer ratio analysis. Global Biogeochemical Cycles 25, GB2008. 
[64] van der Star, W. R. L., Abma, W. R., Blommers, D., Mulder, J.-W., Tokutomi, T., Strous, M., Picioreanu, C., van Loosdrecht, M. C. M., Oct. 2007. Startup of reactors for anoxic ammonium oxidation: Experiences from the first full-scale anammox reactor in Rotterdam. Water Research 41 (18), 4149-63.

[65] Vymazal, J., Jul. 2007. Removal of nutrients in various types of constructed wetlands. The Science of the Total Environment 380 (1-3), 48-65.

[66] Wächter, H., Mohn, J., Tuzson, B., Emmenegger, L., Sigrist, M. W., 2008. Determination of $\mathrm{N} 2 \mathrm{O}$ isotopomers with quantum cascade laser based absorption spectroscopy. Optics Express 16, 9239-9244.

[67] Well, R., Eschenbach, W., Flessa, H., von der Heide, C., Weymann, D., 2012. Are dual isotope and isotopomer ratios of N2O useful indicators for N2O turnover during denitrification in nitrate-contaminated aquifers? Geochimica et Cosmochimica Acta 90, 265-282.

[68] Wrage, N., Velthof, G., van Beusichem, M., Oenema, O., 2001. Role of nitrifier denitrification in the production of nitrous oxide. Soil Biology and Biochemistry 33, $1723-1732$.

[69] Wunderlin, P., Lehmann, M. F., Siegrist, H., Tuzson, B., Joss, A., Emmenegger, L., Mohn, J., Feb. 2013. Isotope signatures of N2O in a mixed microbial population system: constraints on N2O producing pathways in wastewater treatment. Environmental Science \& Technology 47 (3), 1339-48.

[70] Wunderlin, P., Siegrist, H., Joss, A., 2013. Online N2O Measurement: The Next Standard for Controlling Biological Ammonia Oxidation? Environmental Science \& Technology 47, 9567-9568. 
[71] Yamazaki, T., Hozuki, T., Arai, K., Toyoda, S., Koba, K., Fujiwara, T., Yoshida, N., May 2014. Isotopomeric characterization of nitrous oxide produced by reaction of enzymes extracted from nitrifying and denitrifying bacteria. Biogeosciences 11 (10), 2679-2689.

URL http://www. biogeosciences.net/11/2679/2014/

[72] Yang, H., Gandhi, H., Ostrom, N. E., Hegg, E. L., Sep. 2014. Isotopic fractionation by a fungal P450 nitric oxide reductase during the production of N2O. Environmental science \& technology 48 (18), 10707-15.

URL http://www.ncbi.nlm.nih.gov/pubmed/25121461

[73] Yu, R., Kampschreur, M. J., van Loosdrecht, M. C. M., Chandran, K., 2010. Mechanisms and Specific Directionality of Autotropic Nitrous Oxide and Nitric Oxide Generation during Transient Anoxia. Environmental Science \& Technology 44, 13131319.

\section{Figures and tables}




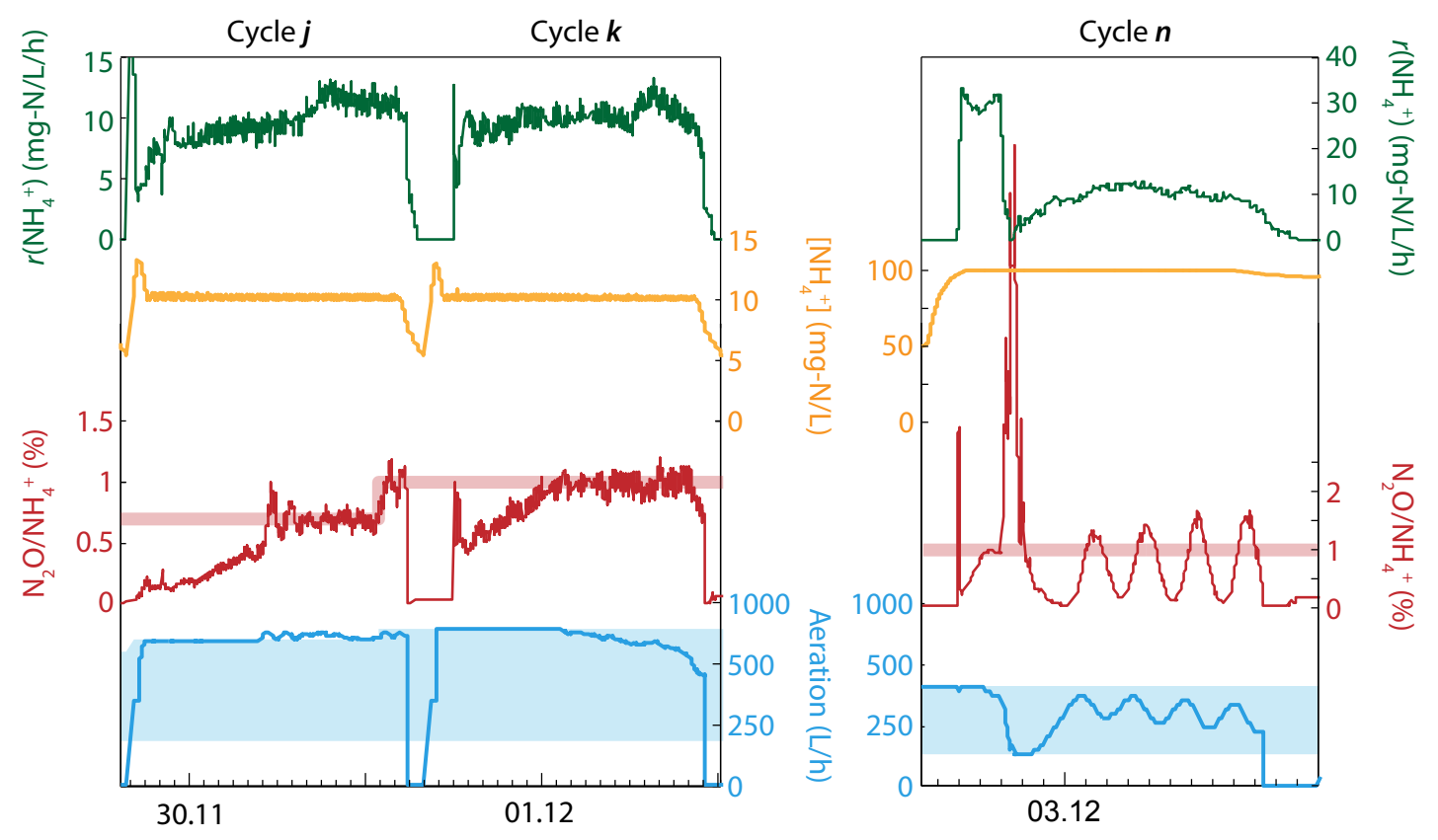

Figure 1: Automatic regulation of aeration flow rate based on online measurement of $\mathrm{N}_{2} \mathrm{O}$ production divided by $\mathrm{NH}_{4}^{+}$consumption rate $r\left(\mathrm{NH}_{4}^{+}\right)$under baseline conditions with low $\mathrm{NH}_{4}^{+}$(left) and high $\mathrm{NH}_{4}^{+}$ (right) concentration. The setpoint for $r\left(\mathrm{~N}_{2} \mathrm{O}\right) / r\left(\mathrm{NH}_{4}^{+}\right)(\%)$ is shown in pale red and the measured value in dark red. The set range for aeration is shown in pale blue and the actual aeration flow is shown in darker blue. Tick mark spacing on the $\mathrm{x}$-axis is one hour. 


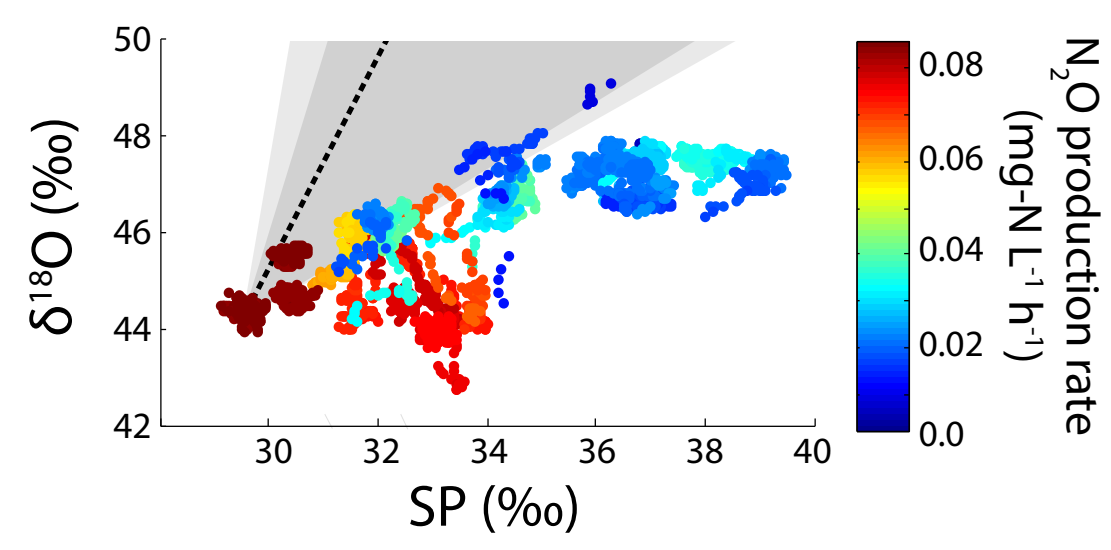

Figure 2: Relationship between $\mathrm{SP}$ and $\delta^{18} \mathrm{O}$ during baseline experiments with low $\mathrm{NH}_{4}^{+}$, shown as points coloured by $\mathrm{N}_{2} \mathrm{O}$ production rate. The expected relationship using the mean $\epsilon_{18} / \epsilon_{\mathrm{SP}}$ from previous studies (see Table S2) is shown as a dashed line and the dark grey shading shows the $1 \sigma$ error; the pale grey shading shows the maximum and minimum slopes from previous studies. These estimates assume that deviation from the measured $\mathrm{SP}$ and $\delta^{18} \mathrm{O}\left(30.2\right.$ and $44.1 \%$ respectively) at an $\mathrm{N}_{2} \mathrm{O}$ production rate of $0.09 \mathrm{mg}-\mathrm{N} \mathrm{L}^{-1} \mathrm{~h}^{-1}$ is solely due to $\mathrm{N}_{2} \mathrm{O}$ reduction. Slope from Well et al. [67] added to determination of mean slope in revised version; see Table S2. 


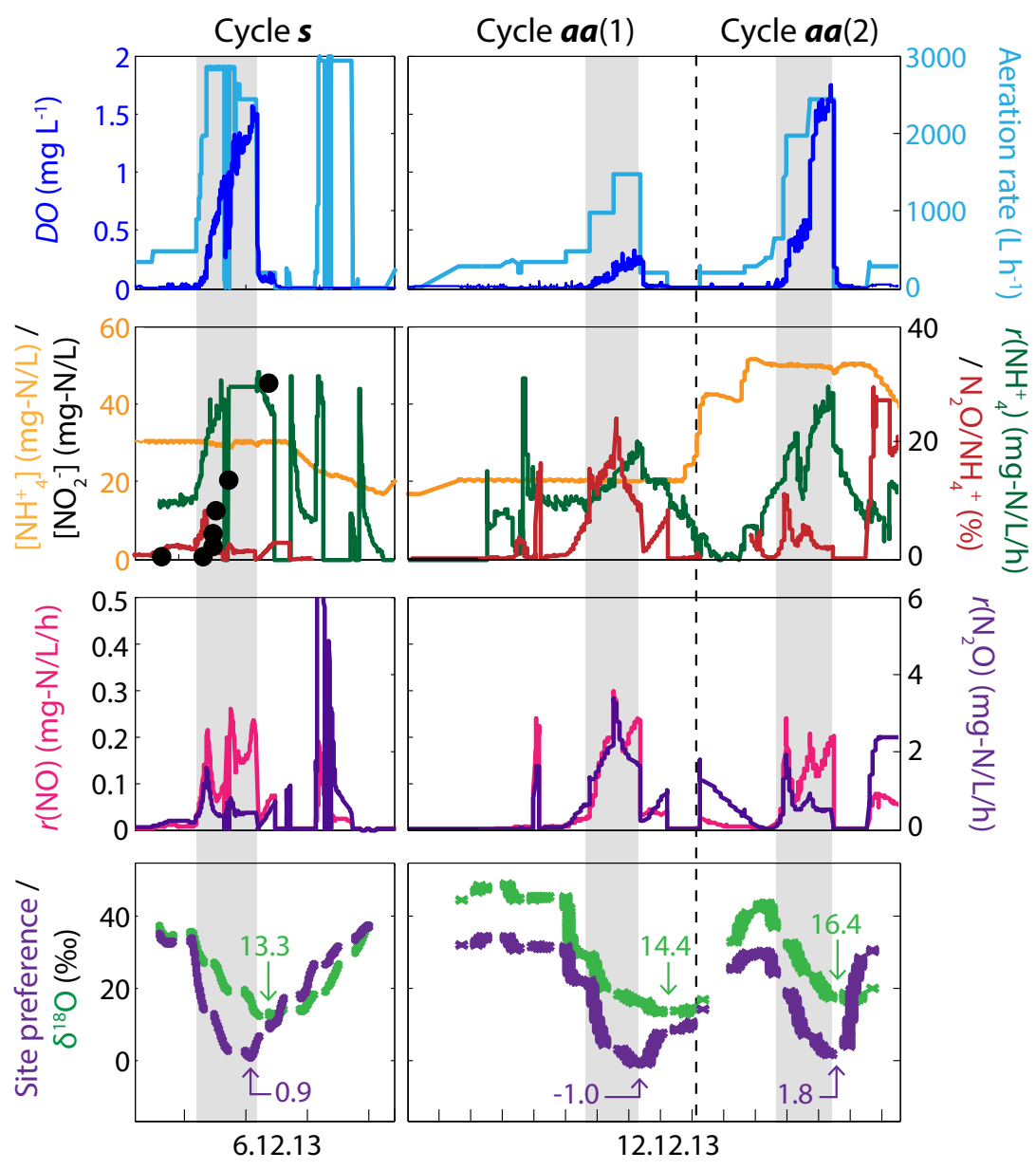

Figure 3: High aeration experiments with normal $\mathrm{NH}_{4}^{+}$setpoint during cycles $s$ and $a a(1)$ and with high $\mathrm{NH}_{4}^{+}$setpoint during cycle $a a(2)$. Cycles $a a(1)$ and $a a(2)$ are divided with a dashed line. The top panel shows the increase in aeration (light blue) and the resultant increase in $D O$ (dark blue); periods where aeration and $D O$ were elevated are highlighted with grey shading. The $\mathrm{NH}_{4}^{+}$concentration (orange) and consumption rate (dark green), $r\left(\mathrm{~N}_{2} \mathrm{O}\right) / r\left(\mathrm{NH}_{4}^{+}\right)$(red), and $\mathrm{NO}_{2}^{-}$concentration (black circles) are shown in the second panel. The third panel shows the $\mathrm{N}_{2} \mathrm{O}$ and $\mathrm{NO}$ production rates in purple and pink respectively. The $\delta^{18} \mathrm{O}$ (green) and $\mathrm{SP}$ (purple) of $\mathrm{N}_{2} \mathrm{O}$ is shown in the bottom panel, with the minimum values indicated for each experiment. X-axis tickmarks are spaced 1 hour apart. 


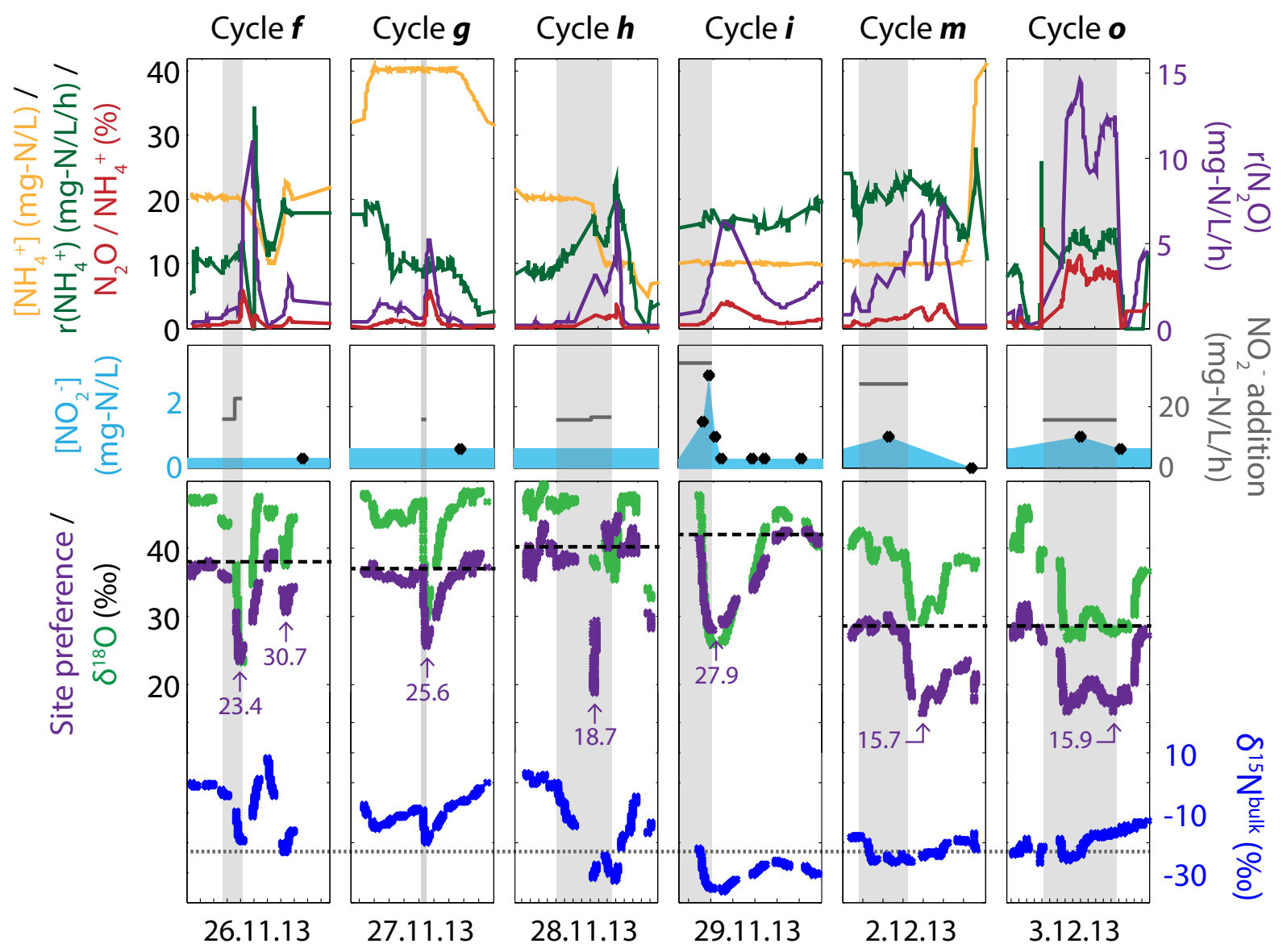

Figure 4: Addition of $\mathrm{NO}_{2}^{-}$(as $\mathrm{NaNO}_{2}$ ) during six cycles with normal aeration. $\mathrm{NO}_{2}^{-}$was continuously added to the reactor during the periods indicated with grey shading. The top panel shows the $\mathrm{NH}_{4}^{+}$ consumption rate $\left(r\left(\mathrm{NH}_{4}^{+}\right)\right.$; green), the $\mathrm{N}_{2} \mathrm{O}$ production rate $\left(r\left(\mathrm{~N}_{2} \mathrm{O}\right)\right.$; purple), $r\left(\mathrm{~N}_{2} \mathrm{O}\right) / r\left(\mathrm{NH}_{4}^{+}\right)(\%$; red), and the $\mathrm{NH}_{4}^{+}$concentration (yellow). In cycle $o$ the $\mathrm{NH}_{4}^{+}$setpoint was $100 \mathrm{mg}-\mathrm{N} \mathrm{L}^{-1}$ which is off-scale in the figure. In the second panel, the $\mathrm{NO}_{2}^{-}$addition rate is shown as a thick grey line and the $\mathrm{NO}_{2}^{-}$concentration is shown in blue (offline measurements) with the individual measurement points are indicated in black. The bottom panel shows the isotopic composition of offgas $\mathrm{N}_{2} \mathrm{O}$. The minimum SP reached after each $\mathrm{NO}_{2}^{-}$addition is indicated and the mean $\mathrm{SP}$ before and after addition for each cycle is shown with a black dashed line. The $\delta^{15} \mathrm{~N}$ of the added $\mathrm{NaNO}_{2}$ salt is shown with a grey dotted line in the bottom panel. X-axis tickmarks are spaced 1 hour apart. 


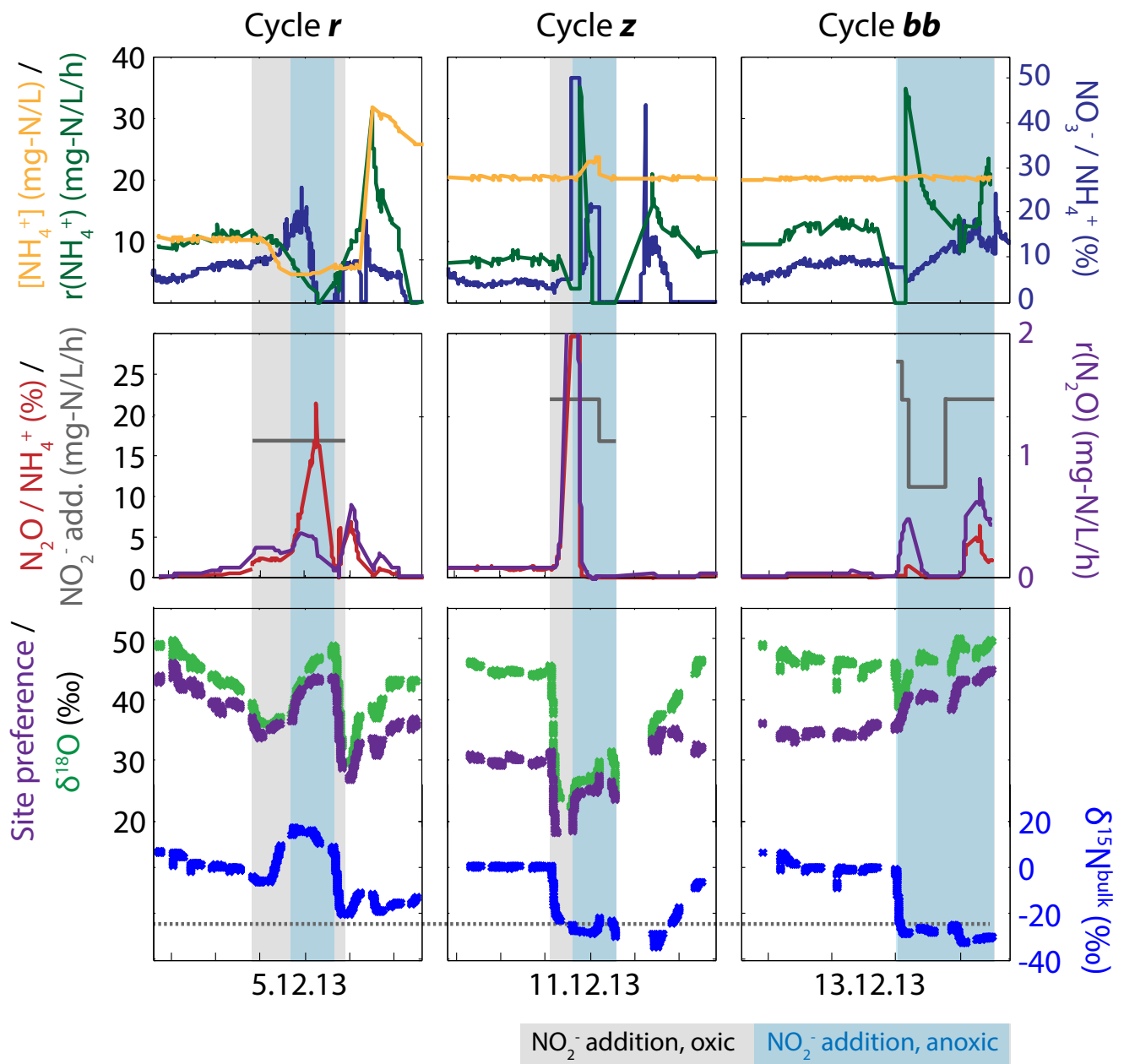

Figure 5: Addition of $\mathrm{NO}_{2}^{-}$(as $\mathrm{NaNO}_{2}$ ) during three cycles with $\mathrm{N}_{2}$ purge gas. $\mathrm{NO}_{2}^{-}$was continuously added to the reactor during the periods indicated with grey shading, and $\mathrm{N}_{2}$ was used for aeration during the periods shaded blue, as shown in the legend. The top panel shows the $\mathrm{NH}_{4}^{+}$consumption rate $\left(r\left(\mathrm{NH}_{4}^{+}\right)\right.$; green), the $\mathrm{NH}_{4}^{+}$concentration (yellow) and $\mathrm{NO}_{3}^{-}: \mathrm{NH}_{4}^{+}$(dark blue). The second panel shows the net $\mathrm{N}_{2} \mathrm{O}$ production rate $\left(r\left(\mathrm{~N}_{2} \mathrm{O}\right)\right.$; purple) and $r\left(\mathrm{~N}_{2} \mathrm{O}\right) / r\left(\mathrm{NH}_{4}^{+}\right)\left(\%\right.$; red), and the $\mathrm{NO}_{2}^{-}$addition rate (grey). The isotopic composition of offgas $\mathrm{N}_{2} \mathrm{O}$ is presented in the bottom panel; the $\delta^{15} \mathrm{~N}$ of the added $\mathrm{NaNO}_{2}$ salt is shown with a grey dotted line. X-axis tickmarks are spaced 1 hour apart. 


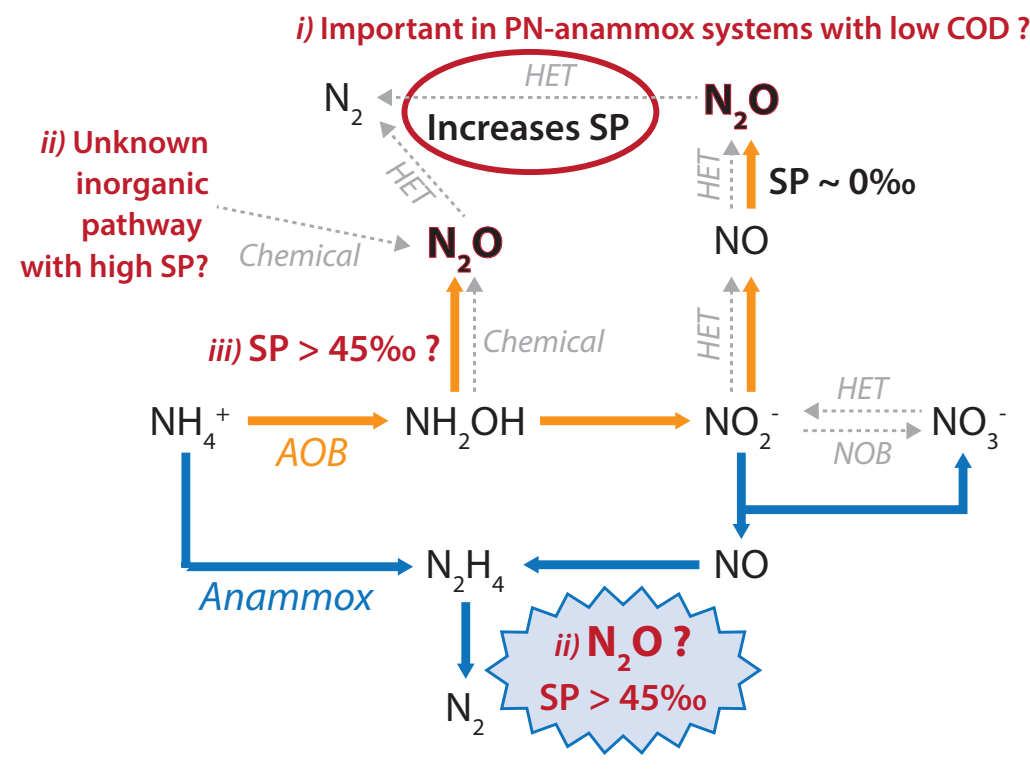

Figure 6: The nitrogen cycle in a $\mathrm{PN}$-anammox reactor. Pathways attributed to ammonia-oxidizing bacteria (AOBs) are shown in yellow, including $\mathrm{N}_{2} \mathrm{O}$ production via $\mathrm{NH}_{2} \mathrm{OH}$ oxidation ( $\mathrm{SP} \sim 33 \%$ ) and via nitrifier denitrification $\left(\mathrm{SP}=0 \%\right.$ ). Anaerobic $\mathrm{NH}_{4}^{+}$oxidizer (anammox) pathways are shown in blue. Other reactions that may be occurring to a minor degree in the system are shown in grey: reduction by heterotrophic denitrifiers (HET), $\mathrm{NO}_{3}^{-}$production by $\mathrm{NO}_{2}^{-}$oxidizing bacteria (NOB), and chemical oxidation of $\mathrm{NH}_{2} \mathrm{OH}$ with $\mathrm{SP} \sim 33 \%$. The four most likely explanations for the high SP values observed throughout this study are shown in red: i) unexpectedly strong heterotrophic $\mathrm{N}_{2} \mathrm{O}$ reduction, ii) unknown inorganic or anammox-associated $\mathrm{N}_{2} \mathrm{O}$ production pathway, or iii) the SP end-member for $\mathrm{NH}_{2} \mathrm{OH}$ has been underestimated in previous studies. 


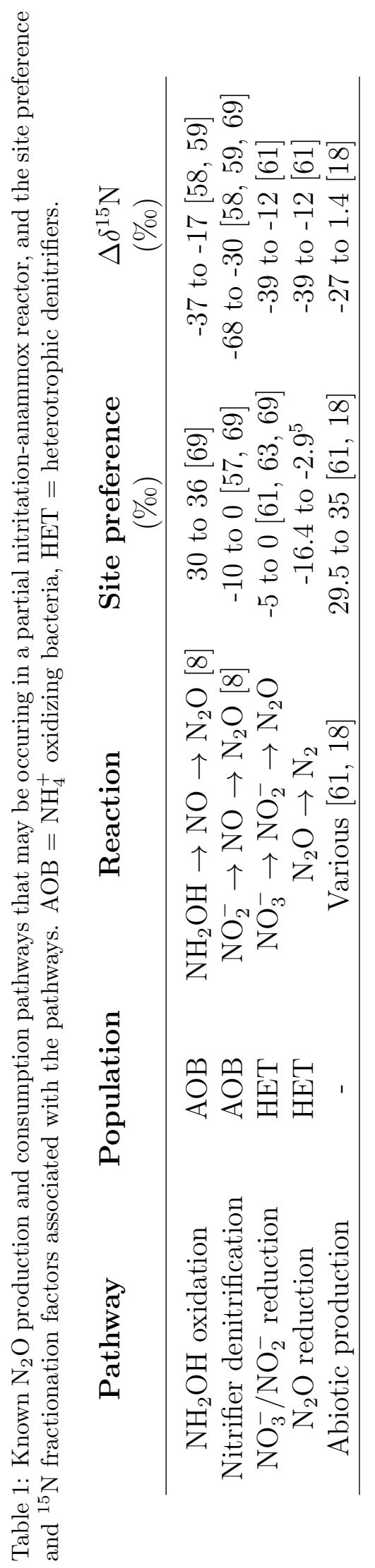

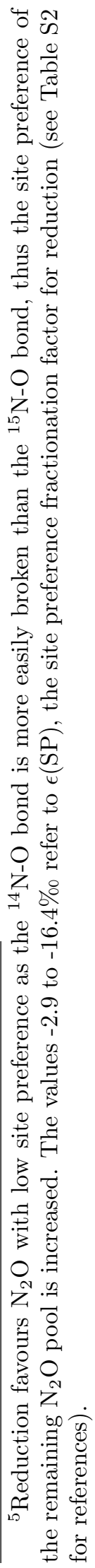




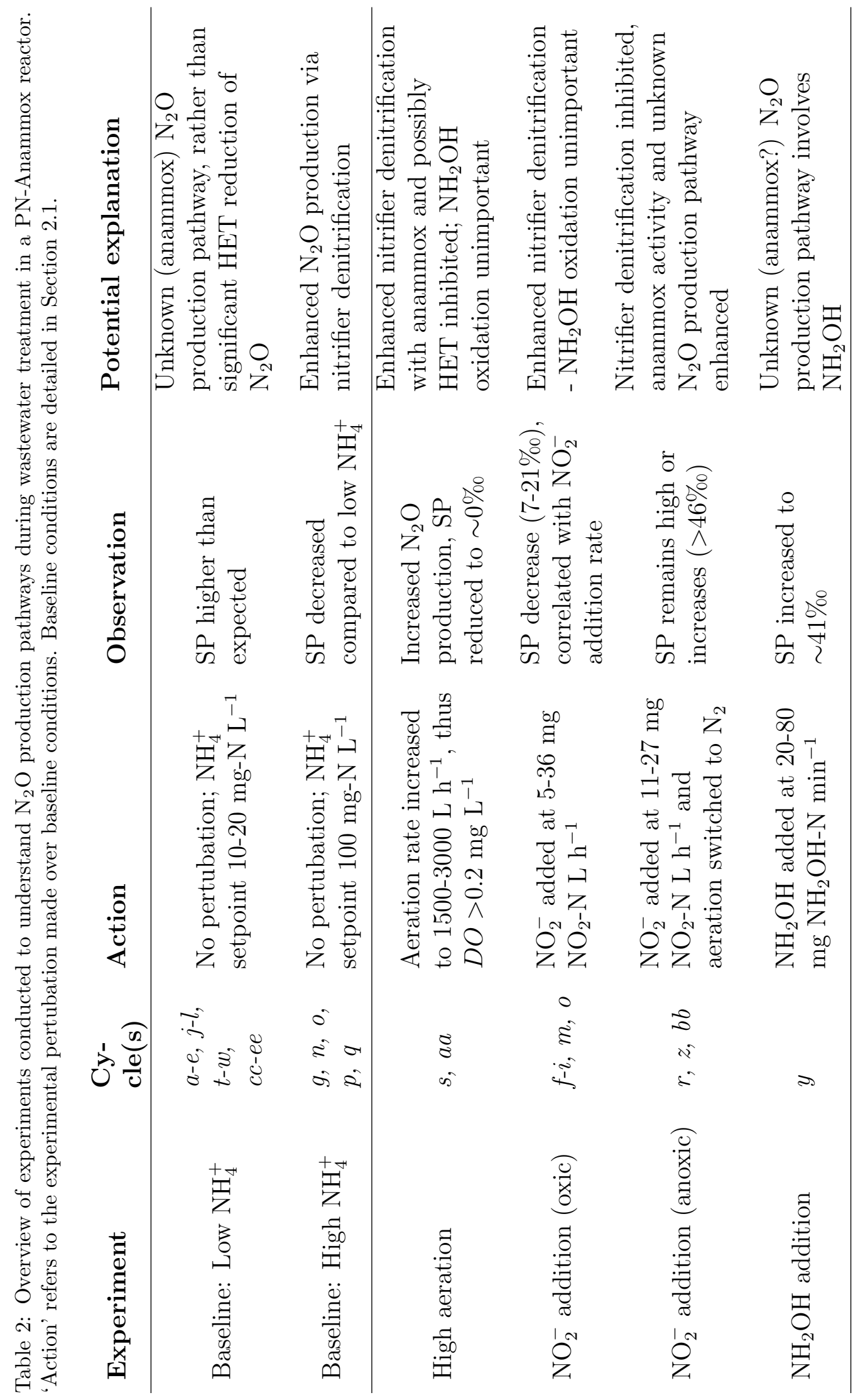

